\title{
Trend analysis of aerosol optical thickness and Ångström exponent derived from the global AERONET spectral observations
}

\author{
J. Yoon, W. von Hoyningen-Huene, A. A. Kokhanovsky, M. Vountas, and J. P. Burrows \\ Institute of Environmental Physics, University of Bremen, Bremen, Germany \\ Correspondence to: J. Yoon (yoon@iup.physik.uni-bremen.de)
}

Received: 19 July 2011 - Published in Atmos. Meas. Tech. Discuss.: 18 August 2011

Revised: 16 May 2012 - Accepted: 16 May 2012 - Published: 6 June 2012

\begin{abstract}
Regular aerosol observations based on wellcalibrated instruments have led to a better understanding of the aerosol radiative budget on Earth. In recent years, these instruments have played an important role in the determination of the increase of anthropogenic aerosols by means of long-term studies. Only few investigations regarding longterm trends of aerosol optical characteristics (e.g. aerosol optical thickness (AOT) and Ångström exponent (ÅE)) have been derived from ground-based observations. This paper aims to derive and discuss linear trends of AOT (440, 675, 870 , and $1020 \mathrm{~nm}$ ) and $\AA \mathrm{E}$ (440-870 nm) using AErosol RObotic NETwork (AERONET) level 2.0 spectral observations. Additionally, temporal trends of coarse- and fine-mode dominant AOTs (CdAOT and FdAOT) have been estimated by applying an aerosol classification based on accurate $\AA \mathrm{E}$ and Angström exponent difference ( $\mathrm{AED}$ ). In order to take into account the fact that cloud disturbance is having a significant influence on the trend analysis of aerosols, we introduce a weighted least squares regression depending on two weights: (1) monthly standard deviation $\left(\sigma_{t}\right)$ and (2) number of observations per month $\left(n_{t}\right)$.

Temporal increase of FdAOTs $(440 \mathrm{~nm})$ prevails over newly industrializing countries in East Asia (weighted trends; $+6.23 \% \mathrm{yr}^{-1}$ at Beijing) and active agricultural burning regions in South Africa $\left(+1.89 \% \mathrm{yr}^{-1}\right.$ at Mongu). On the other hand, insignificant or negative trends for FdAOTs are detected over Western Europe $\left(+0.25 \% \mathrm{yr}^{-1}\right.$ at Avignon and $-2.29 \% \mathrm{yr}^{-1}$ at Ispra) and North America $\left(-0.52 \% \mathrm{yr}^{-1}\right.$ for GSFC and $-0.01 \% \mathrm{yr}^{-1}$ at MD_Science_Center). Over desert regions, both increase and decrease of CdAOTs $\left(+3.37 \% \mathrm{yr}^{-1}\right.$ at Solar_Village and $-1.18 \% \mathrm{yr}^{-1}$ at Ouagadougou) are observed depending on meteorological conditions.
\end{abstract}

\section{Introduction}

Aerosols directly influence air quality and solar light extinction as well as indirectly influence the cloud microphysics and cloud radiative forcing (Twomey, 1977; Pincus and Baker, 1994; Albrecht, 1989; Ackerman et al., 2000; Haywood and Boucher, 2000). Considerable increase of anthropogenic aerosol from human activities as well as emission pattern change in natural aerosol due to climate change for past decades has complicated assessing the aerosol direct and indirect effects on the Earth climate system. These situations lead to the fact that the impact of aerosols on climate change still remains at "med-low" or "low" level of scientific understanding (IPCC, 2007).

Recently, several studies based on long-term records from the well-calibrated space instruments (e.g. Sea-viewing Wide Field-of-view Sensor - SeaWiFS, Multi-angle Imaging SpectroRadiometer - MISR, and Moderate Resolution Imaging Spectroradiometer - MODIS, and Along Track Scanning Radiometer - ATSR) have contributed significantly to the understanding of global aerosol trends (Yoon et al., 2011; Zhang and Reid, 2010; Yu et al., 2009; Karnieli et al., 2009; Thomas et al., 2010). Related to these trends, a hypothesis of global brightening or dimming has been discussed as well (Wild et al., 2005, 2007; Ohmura, 2006; Stanhill, 2007; Norris and Wild, 2007; Streets et al., 2009). However, aerosol retrievals based on satellite observations often have serious uncertainties caused by instrument calibration and assumptions within the algorithms (Li et al., 2009; Higurashi and Nakajima, 1999; Ignatov and Stowe, 2002; Mishchenko et al., 1999a; Jeong et al., 2005; Kahn et al., 2005, 2007; Li et al., 2009; Kokhanovsky and de Leeuw, 2009; von HoyningenHuene et al., 2011). For polar-orbiting satellite observations, it is difficult to avoid the bias in aerosol sampling caused by

Published by Copernicus Publications on behalf of the European Geosciences Union. 
frequent cloud disturbance (Remer et al., 1997; Dubovik et al., 2002a; Jeong and Li, 2005; Jeong et al., 2005; Yoon et al., 2011) and coarse temporal resolution of the observation. Therefore, it is necessary to investigate aerosol trends based on ground-based observations.

The AErosol RObotic NETwork (AERONET) program (http://aeronet.gsfc.nasa.gov/) aims to provide a global distribution of aerosol optical properties and to validate satellite retrievals. Despite aerosols below clouds being underrepresented in the AERONET observation database (Remer et al., 1997; Dubovik et al., 2002a), this network of ground observations provides suitable data for trend analysis of aerosol optical thickness (AOT) at main wavelengths $(440,675,870$, and $1020 \mathrm{~nm}$ ) based on continuous long-term observations with high temporal resolution as well as high accuracy (accuracy; \pm 0.01 ) (Holben et al., 1998, 2001; Eck et al., 1999; Smirnov et al., 2000). Recently, Karnieli et al. (2009) and de Meij et al. (2010) have discussed AOT trends using longterm AERONET data and have compared them with satellite observations (e.g. MISR and MODIS) and model simulations (e.g. Co-operative Programme for Monitoring and Evaluation of the Long-range Transmission of Air Pollutants - EMEP, the Region Emission Inventory - REAS - and the Intergovernmental Panel on Climate Change - RCP 3PD scenario). However, they have published no further information about the uncertainty of cloud disturbances and the influences of aerosol classification in the AOT trend analysis. The cloud disturbances lead to serious uncertainties in the trend analysis by decreasing the number of aerosol observations $\left(n_{t}\right)$ per temporal interval during persistent cloudiness, thus leading to problems with the statistical representativeness (Yoon et al., 2011). Therefore, this paper introduces weighted trends using monthly standard deviation and number of observations to reduce cloud uncertainties in the trend analysis.

Additionally, without applying a classification of aerosol types, the trend studies are only of limited use in the understanding why the aerosol loading changes in time. With this respect, spectral AOT observations are utilized to derive the Ångström exponent ( $\mathrm{E}$ ) (Ångström, 1929) indicating the mean size of particles. In general, submicron or supermicron aerosols have higher or lower ÅEs accordingly. However, $\AA \mathrm{E}$ is not an ideal indicator to show the exact average size of particles as it also is dependent on aerosol absorption and size distribution (Kaskaoutis and Kambezidis, 2008). Another candidate for aerosol classification is utilizing the aerosol optical properties (e.g. volume size distribution and single scattering albedo (SSA)) from AERONET inversion process. However, these could hardly be used to classify aerosol types because of additional retrieval filters resulting in a large loss of data. For example, the volume size distribution is only valid for solar zenith angle $>50^{\circ}$ and SSA needs an additional criterion: AOT $(440 \mathrm{~nm})>0.4$ (Dubovik et al., 2000).
Over the last two decades, there have been several studies of $\AA \mathrm{E}$ curvature related to the aerosol size distribution (Kaufman, 1993; Eck et al., 1999; O'Neill et al., 2001a,b, 2003, 2005; Schuster et al., 2006; Gobbi et al., 2007; Reid et al., 1999; Kaskaoutis et al., 2007, 2011b). The relationships described in these papers provide a more suitable framework to classify aerosol types using ÅE and Ångström exponent difference (ÅED) since it can minimize the data loss in the classification process. Therefore, if considering the significance of data number in the trend analysis, the present paper attempts to analyze the temporal trends of coarse- and fine-mode dominant AOT (CdAOT and FdAOT) separately by applying such aerosol classification.

The present study aims to investigate and analyze the longterm trends of AERONET level 2.0 AOT, CdAOT, FdAOT $(440,675,870$, and $1020 \mathrm{~nm})$, and $\AA \mathrm{E}(440-870 \mathrm{~nm})$ at several stations. For this purpose, the second section describes in detail the methodology used for the selection of suitable AERONET stations, the weighted least squares regression to consider the cloud uncertainty, and the classification of coarse- and fine-mode dominant aerosols. In the third section, the aerosol trends at the specific AERONET stations are discussed regionally. The conclusions are summarized in the final section.

\section{Methodology}

For a reliable analysis of the aerosol trends based on the ground observation, new approaches are introduced: (1) the selection criteria for the AERONET stations having sufficient and nearly-complete multi-year data sets, (2) the weighted least squares regression to consider cloud uncertainty, and (3) the classification of coarse- and fine-mode dominant aerosols.

\subsection{Selection criteria for suitable AERONET stations}

The AERONET program has provided high quality aerosol products for the past decades over roughly 850 global stations. However, not all stations distribute a sufficiently large temporal record suitable for a trend analysis. Firstly, we distinguished suitable AERONET stations having a sufficiently large record per month. The number of observations $\left(n_{t}\right)$ per month $(t)$ basically depends on the seasonal daytime length, the station's location, the operational instrument status, the cloud disturbance, and the verification process of data quality. To obtain statistically meaningful monthly average values, a large $n_{t}$ is highly required as the sample average based on a larger sample number is closer to the real average. Therefore, we have defined the minimum $n_{t}$ of 300 per month (10 observations per day) to consider a reliable monthly average value. Another important issue in the trend analysis is that the annual data should be complete yearly sets in order to avoid a bias in particular seasons. In 

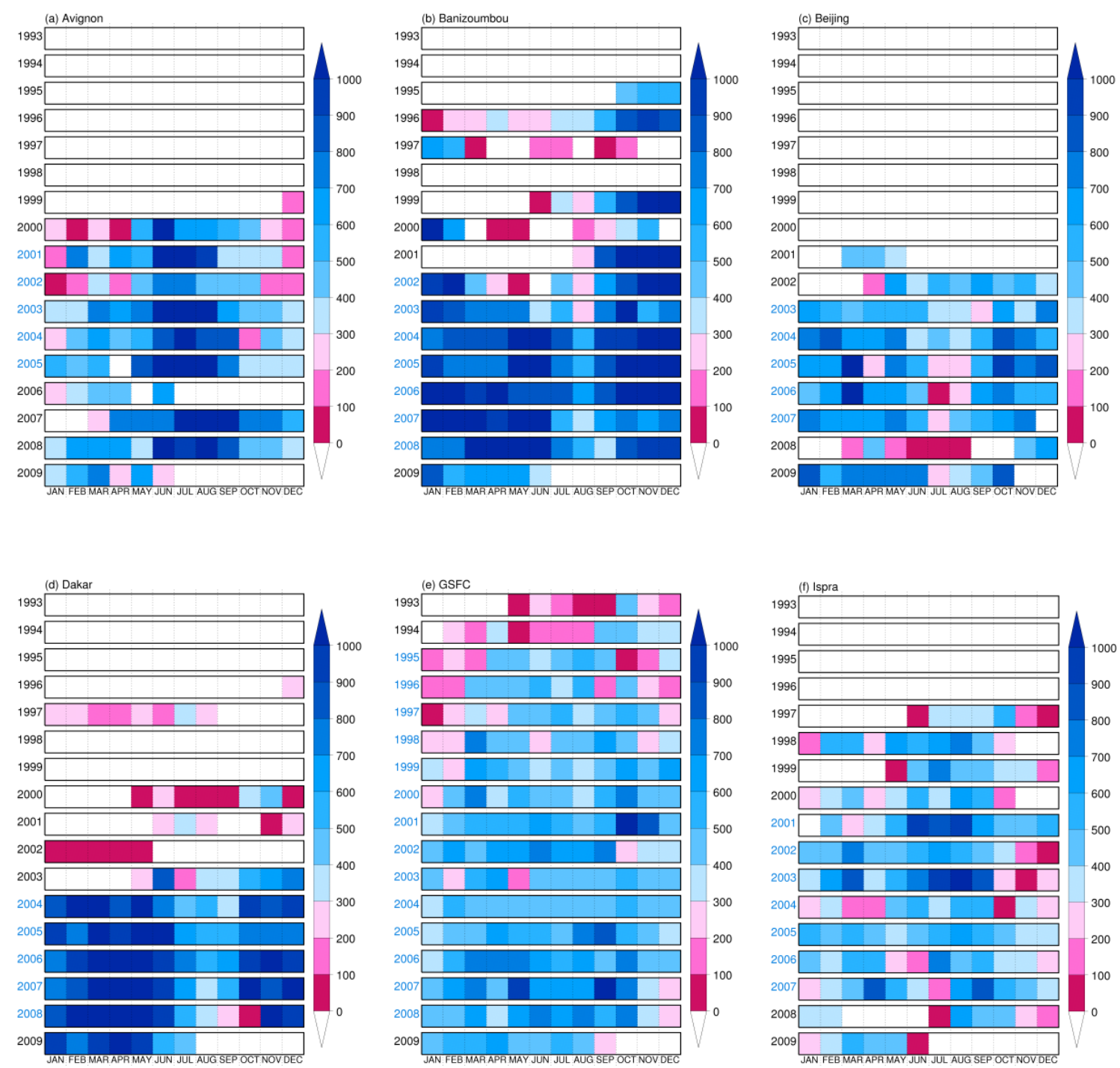

Fig. 1. The monthly observation numbers of level 2.0 AOT $(440 \mathrm{~nm})$ at the AEROET stations: (a) Avignon, (b) Banizoumbou, (c) Beijing, (d) Dakar, (e) GSFC, (f)Ispra, (g) Mauna_Loa, (h) MD_Science_Center, (i) Mongu, (j) Ouagadougou, (k) SEDE_BOKER, (l) Sevilleta, (m) Shirahama, (n) Skukuza, and (o) Solar_Village since 1993. The research period for each station is shown by the blue years at vertical axis.

other words, the absence of continuous monthly averages in the yearly data sets can cause a significant uncertainty in the trend analysis.

Basically, we have set up the following set of criteria to choose suitable AERONET stations:

1. The qualified monthly average is calculated with a $n_{t}$ larger than 300 per month ( 10 observations per day).

2. The complete yearly data set is composed out of more than seven qualified monthly averages.

3. A suitable AERONET station needs to have more than five complete years of observation history.
Although a five-year time series may be insufficiently short for a statistically significant trend analysis, it is a first, pragmatic time span to investigate aerosol temporal change from AERONET observations. Figure 1 shows the $n_{t}$ since 1993 for suitable AERONET stations listed in Table 1. Because each station has a different observation history as well as differently qualified data sets (with respect to the above listed conditions), it is difficult to perform the investigation of aerosol trends during the same time period. The research periods when the data sets satisfy the selection criteria for each station are indicated by blue fields in Fig. 1. Detailed information about the geolocation and the research periods for the selected AERONET stations are listed in Table 1. 

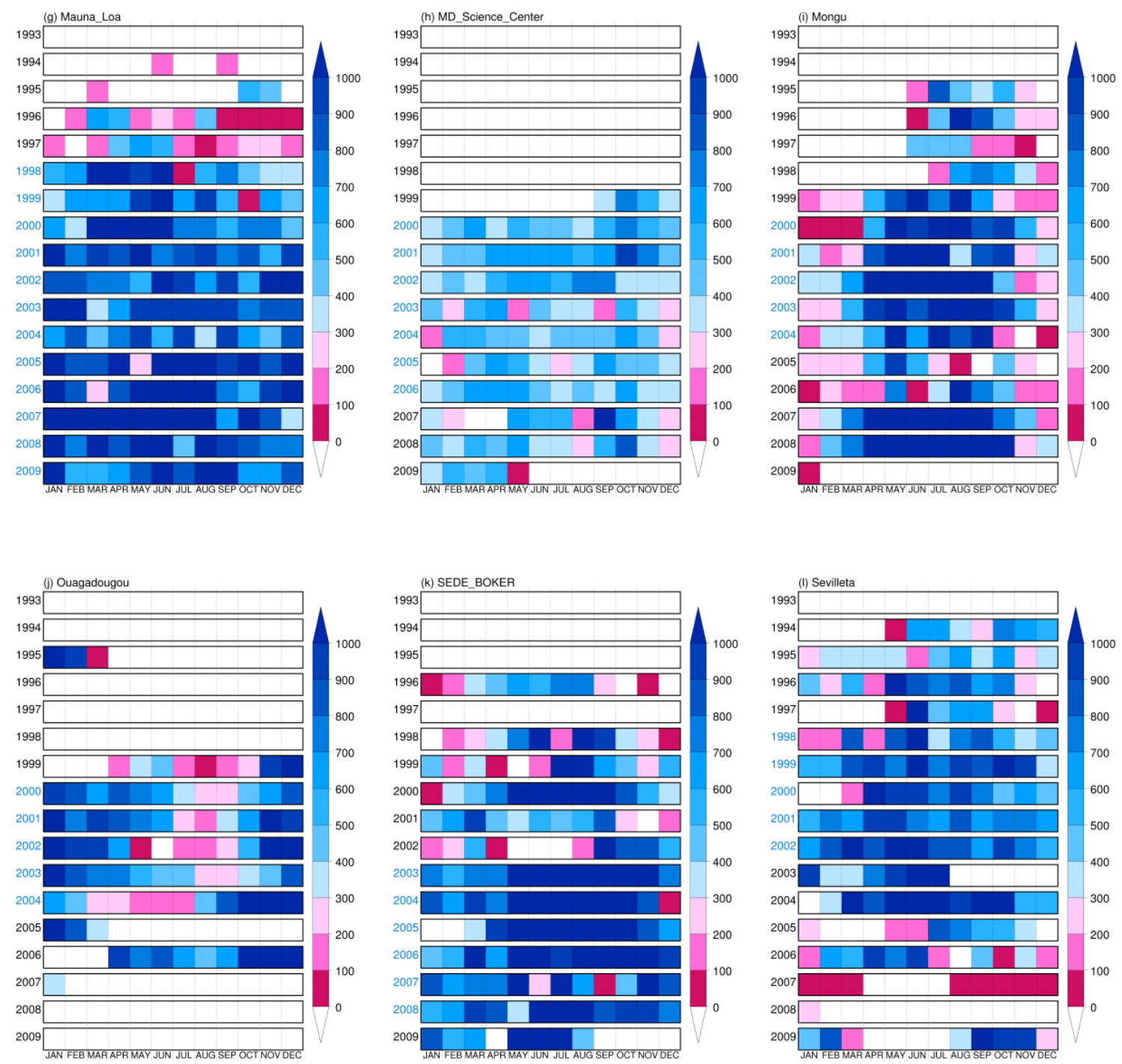

Fig. 1. Continued.

\subsection{Weighted least squares regression}

A simple linear model, which is used by minimizing chisquare error statistics, has been adopted in this study. Let $Y_{t}$ be the monthly AERONET level 2.0 AOT. The linear trend model is given by the following equation:

$Y_{t}=A+B X_{t}+\varepsilon_{t}, \quad t=1, \ldots, T$,

where $A$ is a constant term, $B$ is the magnitude of the trend per year $\left(X_{t}=t / 12\right), \varepsilon_{t}$ is the noise, $t$ is the month index, and $T$ is the total number of months. However, as mentioned before, in order to analyze reliable trends, this simple model needs to take into account cloud disturbance.

Each monthly AOT average has been calculated with different $n_{t}$, which is directly related to the number of cloud occurrence. The trend analysis based on monthly averages during cloudy season may strongly be biased through poor sampling, so that a weighting factor is used to derive the respective trends. Figure 2 depicts the removal ratio of cloud (red line) and quality-unassured (yellow line) observations of AERONET data. If $n_{t}$ is large enough to ignore the other effects (daytime length, station location, and operational instrument status), then main factors affecting $n_{t}$ are the verification process of data quality and (mainly) the cloud disturbance. In Fig. 2, the number of monthly level 2.0 data $\left(n_{t}\right)$ correlate negatively with the cloud removal ratio for most of the stations.

We introduce a weighting factor for the trend analysis:

$\chi^{2}(A, B)=\sum_{t=1}^{T}\left(w t_{t} \times\left(Y_{t}-A-B X_{t}\right)\right)^{2}$,

where, $w t_{t}\left(=\sqrt{n_{t}} / \sigma_{t}\right)$ is the monthly weighting factor defined as ratio of number of observations $\left(n_{t}\right)$ and monthly 

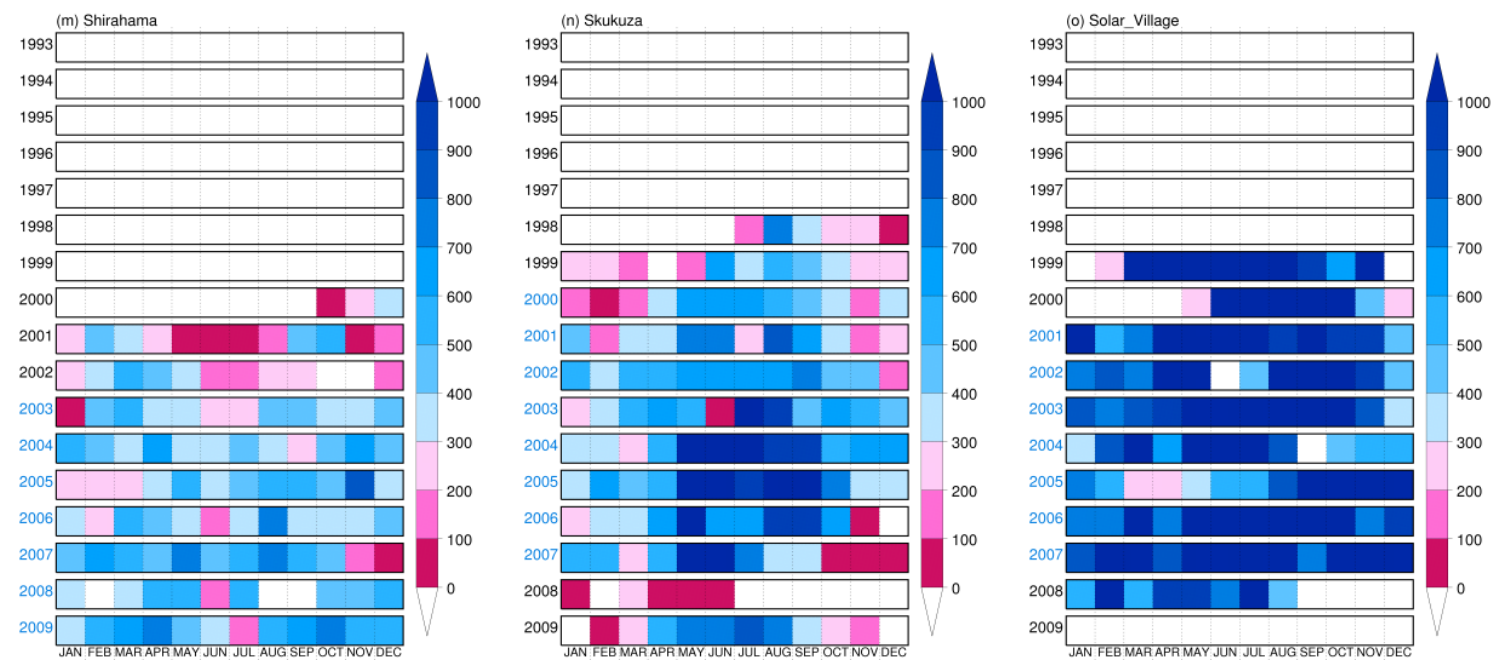

Fig. 1. Continued.

Table 1. Geolocations and research periods of the suitable AERONET stations for aerosol trend analysis in alphabetical order.

\begin{tabular}{lllll}
\hline $\begin{array}{l}\text { Selected AERONET } \\
\text { stations }\end{array}$ & Regions & Countries & $\begin{array}{l}\text { Geolocations } \\
\left.\text { (lat. }\left[^{\circ}\right] / \text { lon. }\left[{ }^{\circ}\right] / \text { alt. }[\mathrm{m}]\right)\end{array}$ & $\begin{array}{c}\text { Research } \\
\text { periods }\end{array}$ \\
\hline (a) Avignon & Western Europe & France & $43.93 / 4.88 / 32$ & $2001 \sim 2005$ \\
(b) Banizoumbou & West Africa & Niger & $13.54 / 2.66 / 250$ & $2002 \sim 2008$ \\
(c) Beijing & East Asia & China & $39.98 / 116.38 / 92$ & $2003 \sim 2007$ \\
(d) Dakar & West Africa & Senegal & $14.39 /-16.96 / 0$ & $2004 \sim 2008$ \\
(e) GSFC & North America & USA & $38.99 /-76.84 / 87$ & $1995 \sim 2008$ \\
(f) Ispra & Western Europe & Italy & $45.80 / 8.63 / 235$ & $2001 \sim 2007$ \\
(g) Mauna_Loa & Free troposphere (Pacific) & USA & $19.54 /-155.58 / 3397$ & $1998 \sim 2009$ \\
(h) MD_Science_Center & North America & USA & $39.28 /-76.62 / 15$ & $2000 \sim 2006$ \\
(i) Mongu & South Africa & Zambia & $-15.25 / 23.15 / 1107$ & $2000 \sim 2004$ \\
(j) Ouagadougou & West Africa & Burkina Faso & $12.20 /-1.40 / 290$ & $2000 \sim 2004$ \\
(k) SEDE_BOKER & Middle East & Israel & $30.86 / 34.78 / 480$ & $2003 \sim 2008$ \\
(l) Sevilleta & North America & USA & $34.35 /-106.89 / 1477$ & $1998 \sim 2002$ \\
(m) Shirahama & East Asia & Japan & $33.69 / 135.36 / 10$ & $2003 \sim 2009$ \\
(n) Skukuza & South Africa & South Africa & $-24.99 / 31.59 / 150$ & $2000 \sim 2007$ \\
(o) Solar_Village & Middle East & Saudi Arabia & $24.91 / 46.40 / 764$ & $2001 \sim 2007$ \\
\hline
\end{tabular}

standard deviation $\left(\sigma_{t}\right)$. Monthly standard deviation is by itself a suitable weight as it statistically shows the representativeness (variability or diversity caused by cloud contamination or severe aerosol events) of the average. In the following we will estimate the cloud uncertainty through the comparison between the weighted and unweighted trends.

\subsection{Classification of coarse- and fine-mode dominant aerosols}

In order to quantify the change in anthropogenic (generally, fine-mode dominant) and natural (coarse-mode dominant) aerosols, an aerosol classification needs to be applied as well. The AERONET inversion process (so-called version 2 Dubovik retrievals) (Dubovik and King, 2000; Dubovik et al., 2000, 2002a,b, 2006; Sinyuk et al., 2007) generates various aerosol characteristics such as volume size distribution and SSA. However, the data are only provided for the following conditions: solar zenith angle $(\theta)>50^{\circ}$ for volume size distribution, and AOT $(440 \mathrm{~nm})>0.4$ and $\theta>50^{\circ}$ for SSA (Dubovik et al., 2000). Figure 3 shows the normalized frequency of AOT $(440 \mathrm{~nm})$ and solar zenith angle at the selected AERONET stations. Generally, the normalized frequency (histogram) distributions of AOT $(440 \mathrm{~nm})$ are skewed and have long tails towards larger values of AOT. The percentage of the AERONET level 2.0 inversion data (volume size distribution and SSA) to the total observations is indicated as a pie chart on the lower-left hand side in Fig. 3. In most cases, it is difficult to use the volume size distribution and SSA for aerosol classification because of a 

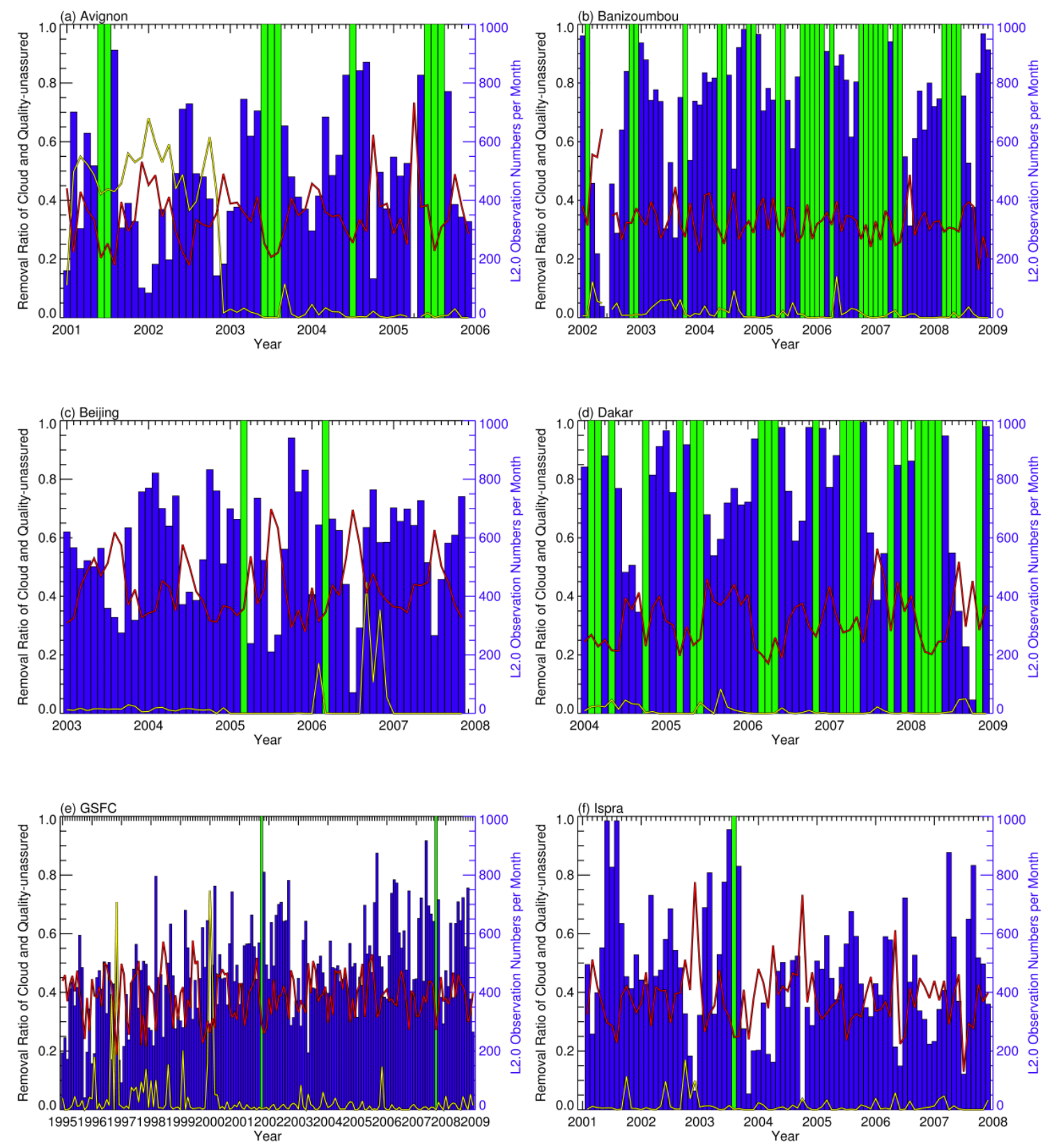

Fig. 2. The removal ratio of cloud (red line) and quality-unassured (yellow line) cases to AERONET level 2.0 data (blue bar) within each of research period at the several AERONET stations. Green bars mean that the observation numbers per month are over 1000 times.

low proportion to total observations meeting the conditions mentioned above. The AERONET also provides level 2.0 fine/coarse mode AOTs $(500 \mathrm{~nm})$ determined by the spectral deconvolution algorithm (SDA) of O'Neill et al. (2003). These values are based on quadratic fit of the spectral AOTs at 5 channels from 380 to $870 \mathrm{~nm}$, and also agree well with the version 2 Dubovik retrievals of fine/coarse mode AOTs (Eck et al., 2010). However, the additional data loss caused by the level 2.0 SDA criteria (http://aeronet.gsfc.nasa.gov/) makes it difficult to analyze the weighted trend based on the number of retrievals/observations for taking account of cloud disturbance. Therefore, if considering the significance of data number in the weighted trend method and thereby trying to minimize the data loss, we propose a classification of coarse- and fine-mode dominant aerosols using ÅE and ÅED retrievals from AERONET level 2.0 direct sun data. ÅE and 

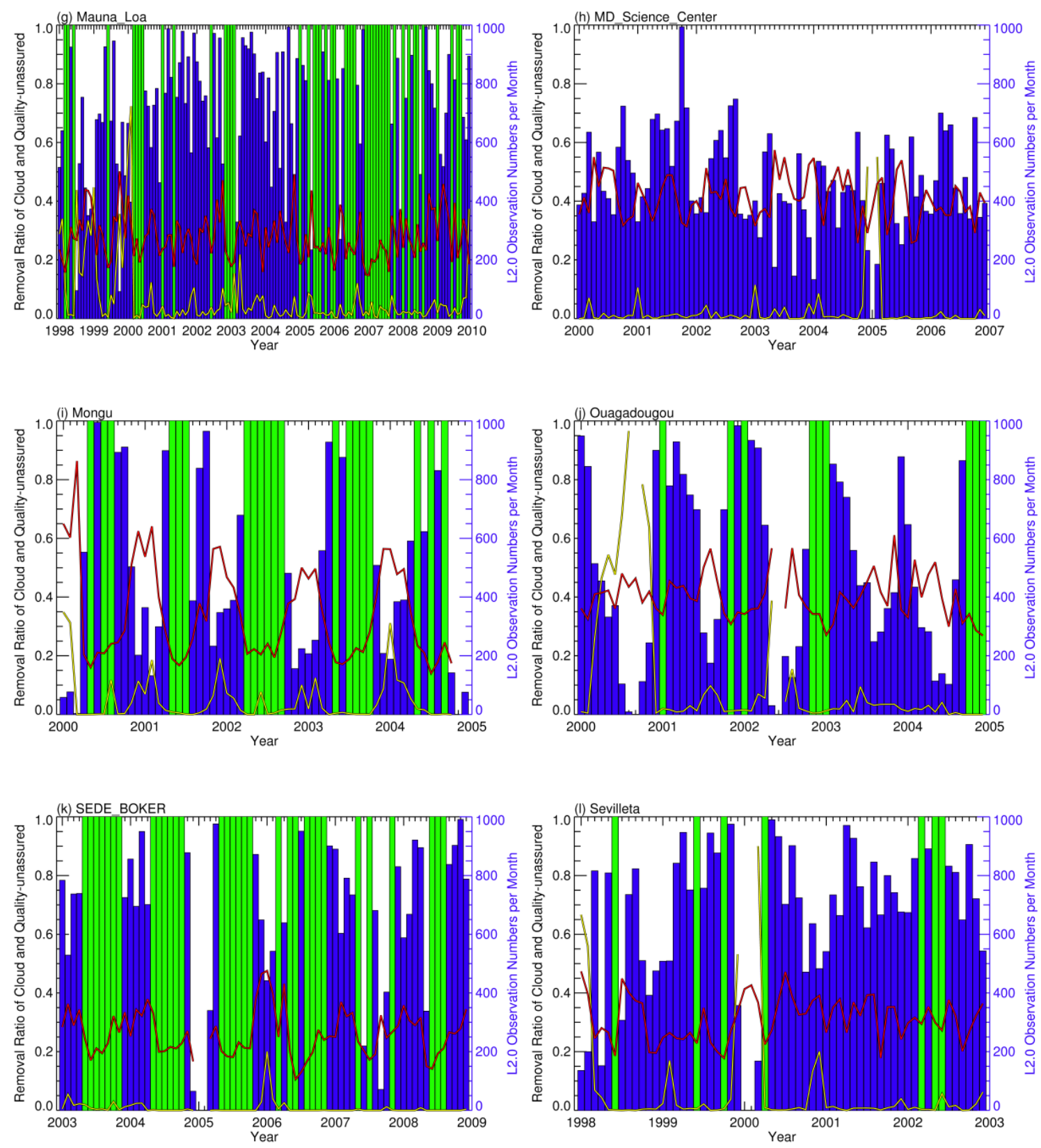

Fig. 2. Continued.

ÅED are defined as:

$$
\begin{aligned}
\AA \mathrm{E} & =-\frac{\ln \left(\delta_{\lambda 1} / \delta_{\lambda 3}\right)}{\ln (\lambda 1 / \lambda 3)}, \\
\AA \mathrm{ED} & =-\frac{\ln \left(\delta_{\lambda 1} / \delta_{\lambda 2}\right)}{\ln (\lambda 1 / \lambda 2)}+\frac{\ln \left(\delta_{\lambda 2} / \delta_{\lambda 3}\right)}{\ln (\lambda 2 / \lambda 3)},
\end{aligned}
$$

where, $\delta_{\lambda}$ is AOT at wavelengths $(\lambda 1=440 \mathrm{~nm}, \lambda 2=675 \mathrm{~nm}$, and $\lambda 3=870 \mathrm{~nm}$ ).
Several investigations have been previously devoted to the curvature of the spectral dependence of AOT in order to derive more accurate aerosol size information. For example, Kaufman (1993) found that the spectral curvature shows a transition from mixed accumulation and coarse particle modes to a dominant accumulation mode. Eck et al. (1999) investigated the wavelength dependence of the optical depth of biomass burning, urban, and desert dust aerosols. O'Neill et al. (2001a,b, 2003, 2005) and Schuster et al. (2006) presented a detailed analysis and compared simulations and observations in order to investigate the relationship between 

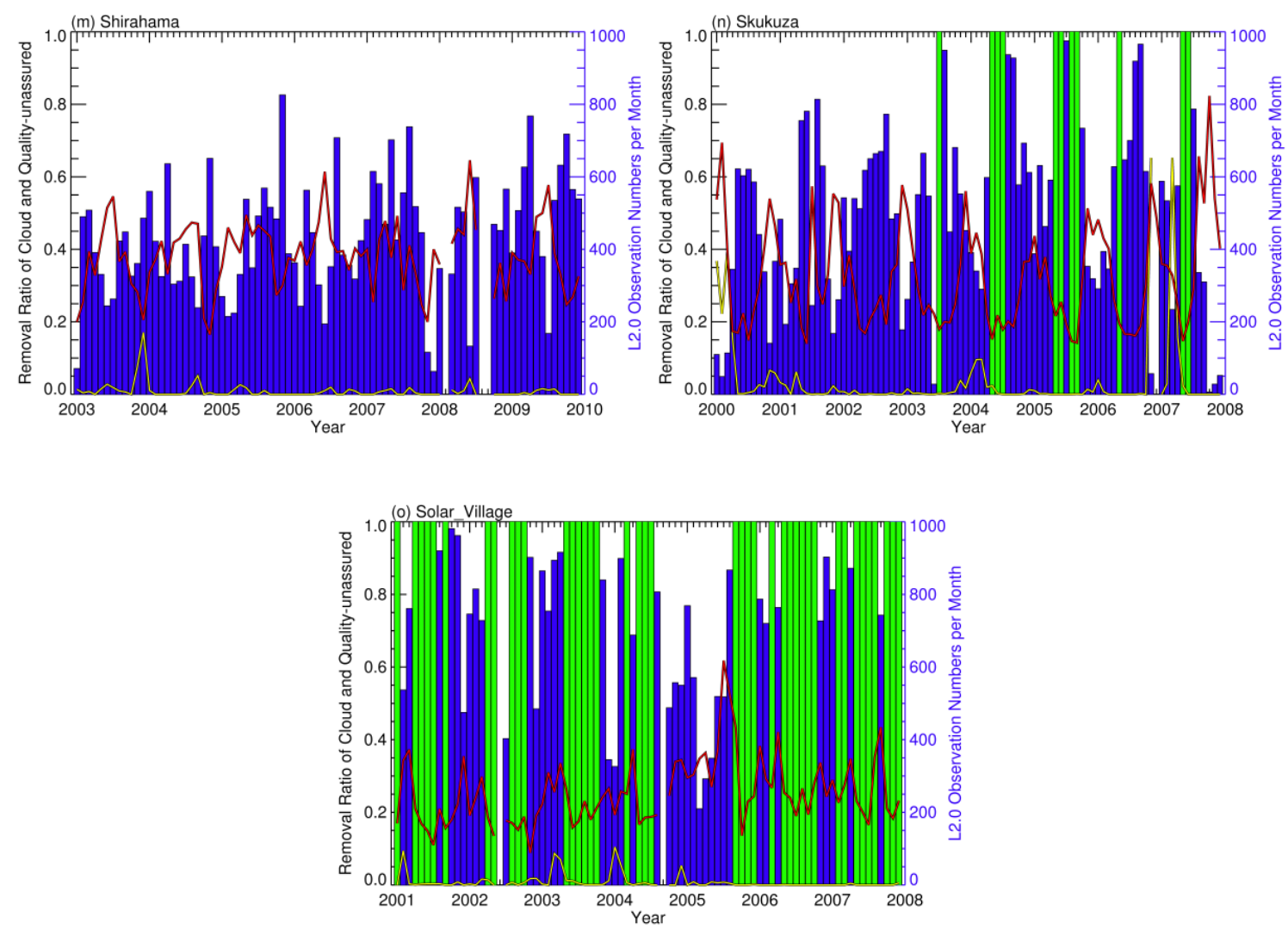

Fig. 2. Continued.

aerosol size distribution and spectral dependence of the AOT. Gobbi et al. (2007) have set up a useful straightforward graphical framework applicable to classify aerosol fine mode fraction of the total AOT at $675 \mathrm{~nm}$ using ÅED as a measure of the curvature. They have applied the graphical framework to AERONET data and were able characterize different aerosol types such as pollution, mineral dust, and biomass burning. However, none of the above mentioned publications involved their methods in trend analyses. In this study, we build up the classification criteria determined by a similar approach as Gobbi et al. (2007). Even though this classification technique might be problematic as compared to the Dubovik or O'Neill retrievals mentioned before since it relies on only 2 channel computations of $\AA \mathrm{E}$, this is the best way to consider the cloud effects by reducing the data loss in the trend analysis. With Fig. 4, using the Mie theory, we tested the relationship between $\AA \mathrm{E}$ and $\AA \mathrm{ED}$ simulated with many bimodal volume size distributions consisting out of mode radii, widths, fine volume fractions, and refractive indices (approximately 25000 combinations) shown in Table 2. Usually, negative ÅED shows a high proportion of fine mode aerosol for the same $\AA \mathrm{E}$. In this study, we set up the classification using both ÅE and ÅED by $50 \%$ fine volume fraction to total aerosol.
Generally, coarse-mode (fine-mode) dominant aerosols have been classified by lower (higher) values than $\AA \mathrm{E}$ of at least 1.0 (Kaufman, 1993) or 1.4 (Tanré et al., 2001; Pereira et al., 2011; Shinozuka et al., 2011). However, one constant value of $\AA \mathrm{E}$ is not a good threshold to classify the aerosol types (coarse and fine dominant aerosols). Therefore, the new classification criteria determined by $50 \%$ fine volume fraction effectively discriminates coarse- and fine-mode dominant aerosols by higher accuracy $(95.73 \%)$ than using other constant ÅEs ( $75.30 \%$ for $\AA \mathrm{E}$ of 1.0 and $80.82 \%$ for $\AA \mathrm{E}$ of 1.4) based on the Mie simulation in Fig. 4. Figure 5 shows additional Mie simulations (Mishchenko et al., 1999b, 2002) based on aerosol characteristics of typical aerosols (urbanindustrial and mixed, biomass burning, desert dust, oceanic from Dubovik et al., 2002a) to examine the red classification line (i.e. a variable $\AA E$ and $̊ \mathrm{ED}$ determined by $50 \%$ fine volume fraction). Coarse-mode dominant aerosols (desert dust and maritime aerosols) have smaller $\AA \mathrm{E}$ and positive ÅED according to the increase of aerosol loading. As already mentioned, the mean particle size of fine-mode dominant aerosols could increase due to the increase of aerosol loading despite larger fine volume fractions. In addition, the range of ÅE (440-870 nm) for the typical aerosols from Dubovik et al. (2002a) (horizontal bar chart, bottom of Fig. 5) can explain why only one constant value of $\AA \mathrm{E}$ is not enough to 

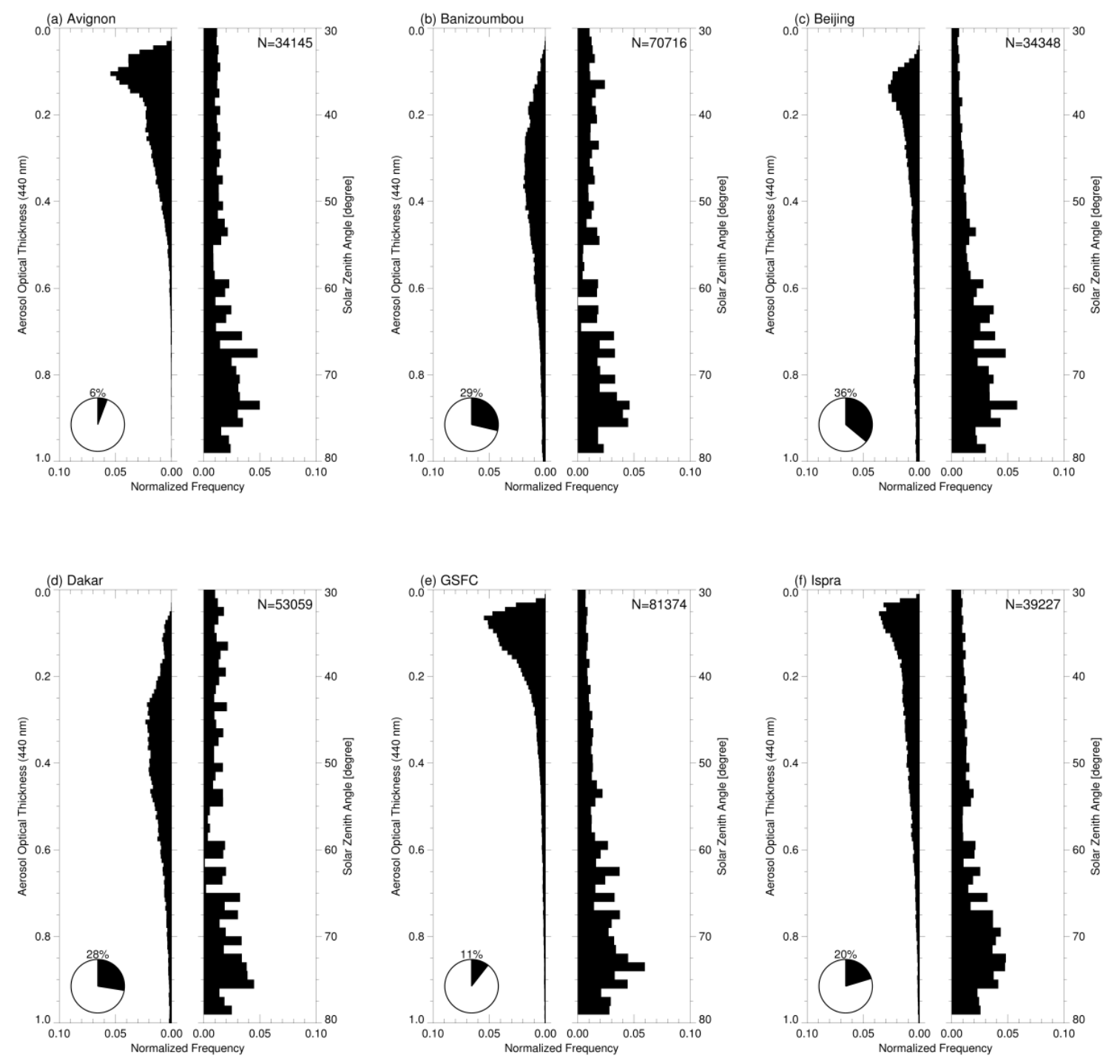

Fig. 3. Normalized frequency of AOT at $440 \mathrm{~nm}\left(\delta_{440}\right)$ and solar zenith angle $(\theta)$ to total observation number $(N)$ at the several AERONET stations. The bin sizes for $\delta 440$ and $\theta$ are 0.01 and $1.0^{\circ}$, respectively. The circle diagram on the lower-left hand means the percentage of AERONET level 2.0 inversion data (e.g. volume size distribution and single scattering albedo - SSA) to total observations. The volume size distribution is provided under $\theta>50^{\circ}$, and SSA is only valid for the criteria; $\delta_{440}>0.4$ and $\theta>50^{\circ}$.

classify coarse- or fine-mode dominant aerosols. These tendencies of $\AA \mathrm{E}$ and $\AA \mathrm{ED}$ are more apparent when looking at application of AERONET data.

Figure 6 shows a scatterplot of $\AA \mathrm{E}$ and ÅED derived from AERONET datasets at the fifteen stations including the red classification line. After applying the classification, the percentages of coarse-mode (C) and fine-mode (F) dominant aerosols are shown as a pie chart at the upper-left hand side of Fig. 6. In order to avoid ÅE errors larger than $30 \%$, we only take into account those observations having AOT $(440 \mathrm{~nm})$ larger than 0.15 (Gobbi et al., 2007). Most $\AA \mathrm{E}$ and $\AA \mathrm{ED}$ from AERONET observations in Fig. 6 are generally in good agreement with Mie simulations in Fig. 5. In other words, the majority of them are positioned within the simulation border (black thick line) and their variations according to increase of aerosol loading are similar to the simulations. As can be seen in Fig. 6 for practically all AERONET stations, a difference in percentage of coarse- and fine-mode dominant aerosols is observed due to different regional aerosol sources and atmospheric conditions. All stations over West Africa (Banizoumbou - C $99 \% \gg$ F $1 \%$, Dakar - C $99 \% \gg$ F $1 \%$, and Ouagadougou - C97\%》F3\%) and Middle East (SEDE_BOKER - C $71 \%>$ F $29 \%$ and Solar_Village $\mathrm{C} 97 \% \gg \mathrm{F} 3 \%$ ) are influenced by coarse-mode dominant aerosols because the regions are close to deserts. In contrast, industrial pollutant and biomass burning aerosols are dominant over Western Europe (Avignon - C $23 \%<$ F $77 \%$ and Ispra - C13\%<F 87\%), South Africa (Mongu - 

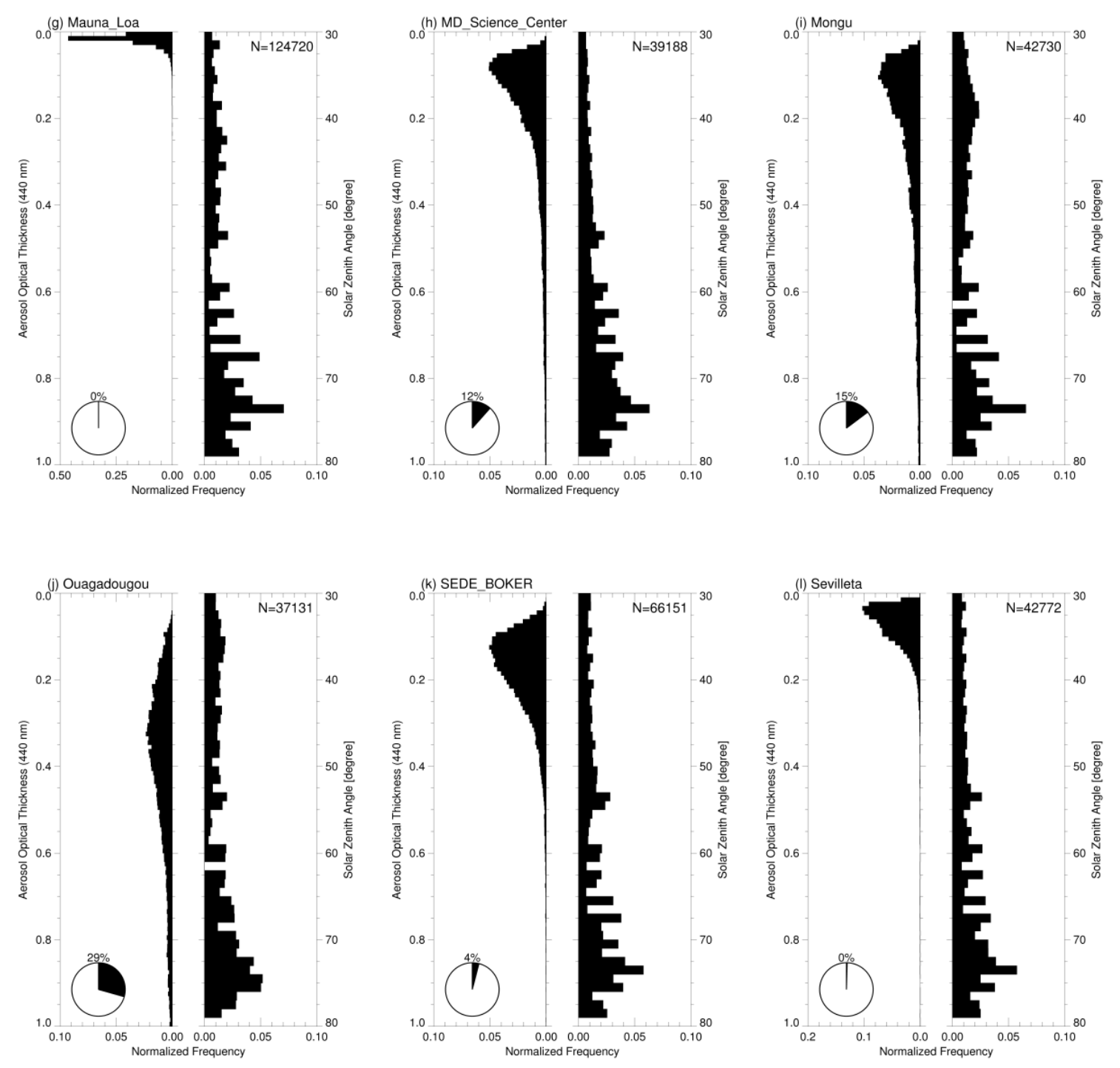

Fig. 3. Continued.

C $6 \% \ll$ F $94 \%$ and Skukuza - C $15 \%<$ F $85 \%$ ), and North America (GSFC - C $9 \% \ll$ F $91 \%$ and MD_Science_Center - $\mathrm{C} 10 \%<\mathrm{F} 90 \%$ ). Especially typical anthropogenic aerosols caused by urbanization and industrialization as well as natural aerosols brought in by strong westerly winds are observed over East Asia (Beijing - C $62 \%>$ F $38 \%$ and Shirahama - C $41 \%<$ F $59 \%)$. The classification is not applicable to data observed at Mauna_Loa and Sevilleta because most AOTs $(440 \mathrm{~nm})$ over these stations were less than 0.15 .

By applying the aerosol classification, it is possible to analyze more reliable trends separately for coarse- and fine-mode dominant aerosols. However, the classification is non-applicable for an extremely small aerosol load over Mauna Loa and Sevilleta stations and the trend analysis of FdAOT for stations dominated by coarse-mode aerosols (such as Banizoumbou, Dakar, Ouagadougou, and So-
lar_Village) might be insignificant because of incomplete yearly data sets.

\section{Trend analysis}

For this part of study, we have selected fifteen AERONET stations providing datasets meeting the requirements specified in Sect. 2.1. In the following sections, the trends for the stations located in several regions (Western Europe, West Africa, South Africa, Middle East, East Asia, North America, and Free troposphere/Pacific) are discussed. The trends of $\AA \mathrm{E}(440-870 \mathrm{~nm})$ and AOT $(440 \mathrm{~nm})$ at the AERONET stations are shown in Fig. 7. For clarification, the error bar is scaled by a factor 10 of the standard error $\left(\sigma_{t} / \sqrt{n_{t}}\right)$, which is inversely used for the weighted trend analysis. Comparison between unweighted (blue line and text on the left upper 

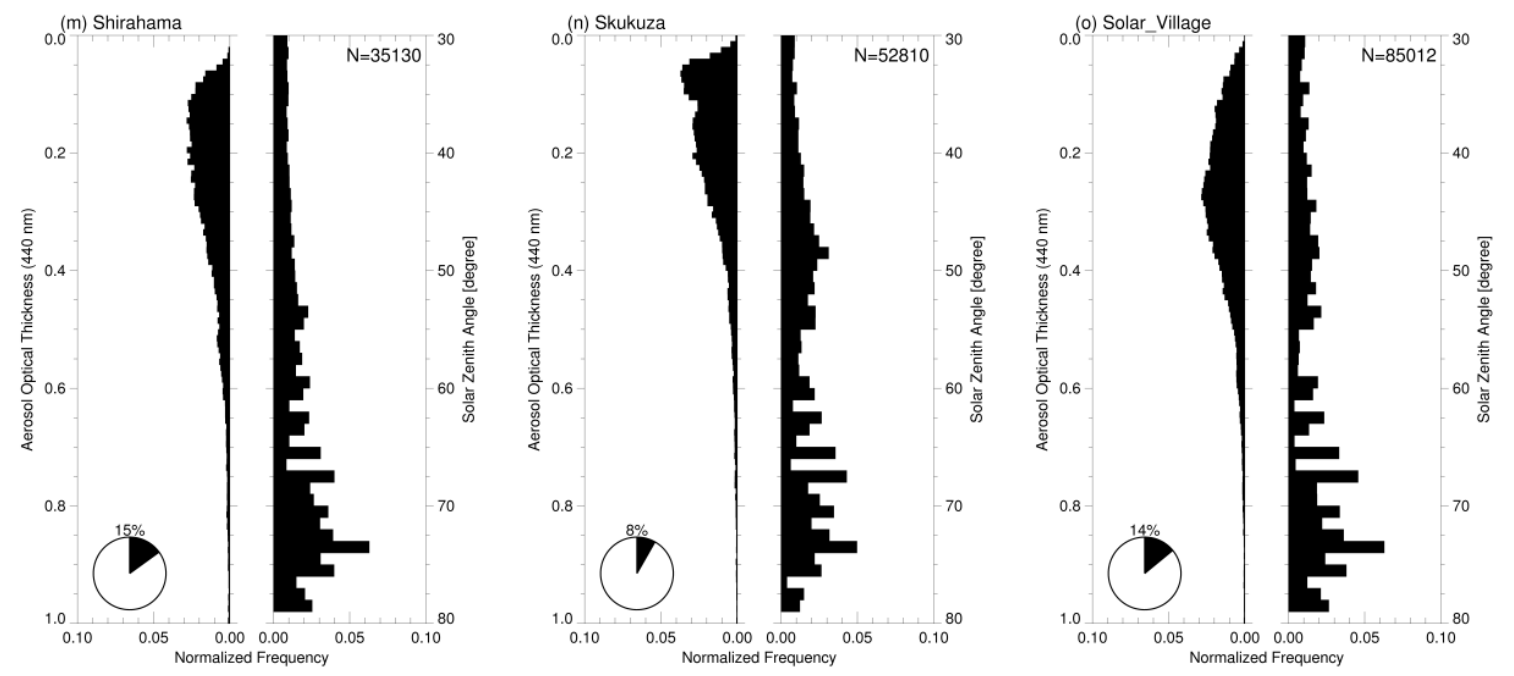

Fig. 3. Continued.

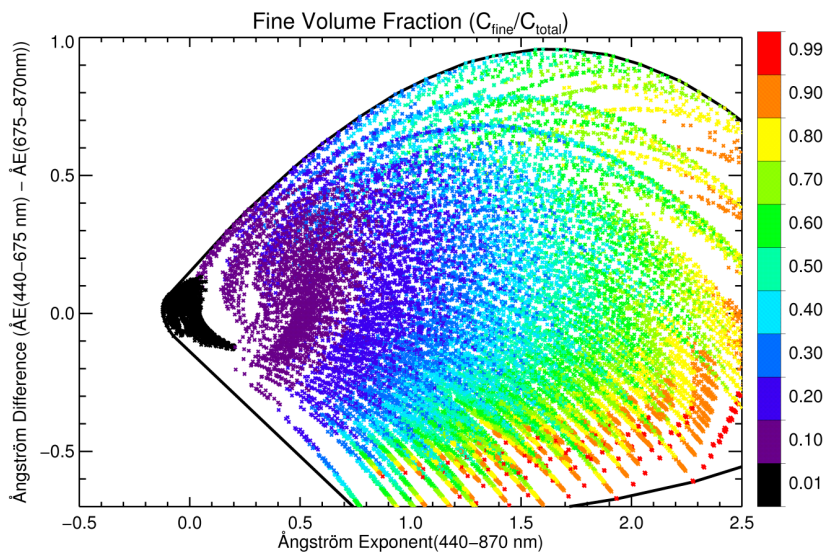

Fig. 4. Simulations of the fine volume fraction as a function of Ångström exponent $(440-870 \mathrm{~nm})$ and Ångström exponent difference ( $\mathrm{E} \mathrm{E}(440-675 \mathrm{~nm})-\AA \mathrm{E}(675-870 \mathrm{~nm}))$ using Mie theory with all combinations of various aerosol optical properties shown in Table 2.

part) and weighted trends (red line and text on the right upper part) allows to estimate the uncertainty caused by cloud disturbance in the trend analysis.

In this part, the main discussions of the aerosol trends are on the basis of the weighted trends of AOT $(440 \mathrm{~nm})$ and ÅE $(440-870 \mathrm{~nm})$. As previously mentioned, a classification of coarse- and fine-mode dominant aerosols, (which is based on the Mie theory) is also introduced in the trend analysis in Fig. 9. Finally, the unweighted and weighted trends of ÅE $(440-870 \mathrm{~nm})$, AOT, CdAOT, and FdAOT $(440 \mathrm{~nm})$ in percent for most of AERONET stations are indicated on the global map in Figs. 8 and 10, and all specific values of both trend analyses are summarized in Tables 3 and 4.

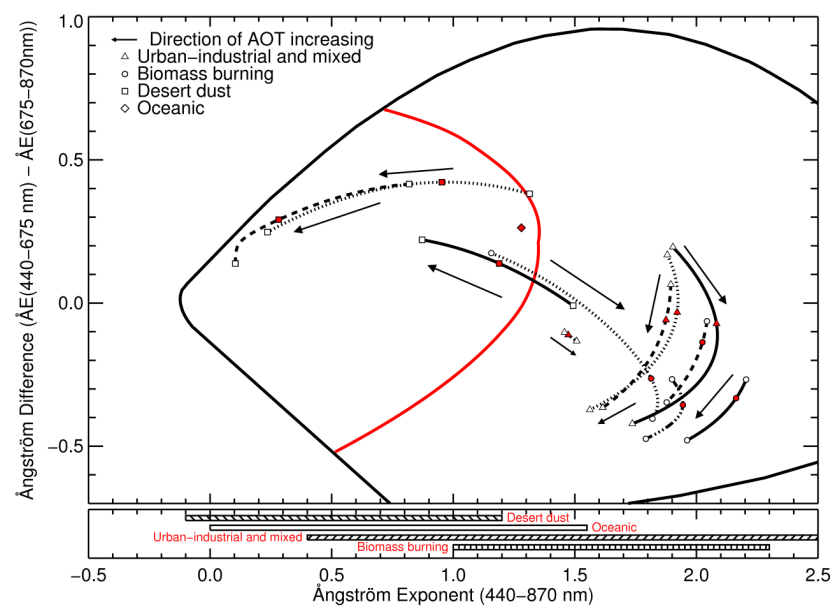

Fig. 5. Mie simulations (solid, dotted, dashed, dash-dot-dot lines) and range of Ångström exponent (440-870 nm) for the typical aerosols (urban-industrial and mixed, biomass burning, desert dust, oceanic) summarized in Dubovik et al. (2002a). The red spot and red line represent the simulations for AOT mean of the typical aerosols and the classification line for two aerosol types (fine- and coarse-mode dominant aerosols), respectively.

\subsection{Western Europe}

The averages of $\AA \mathrm{E}$ shown in Fig. 7 for Avignon $(<\AA \AA \mathrm{E}>=1.43)$ and Ispra $(<\AA \mathrm{E}>=1.51)$ over Western Europe were influenced by industrial, urban, and traffic pollutants, such as ammonium salts of sulphate and nitrate (González et al., 2000; Benkovitz et al., 1996; Kambezidis and Kaskaoutis, 2008; Mazzola et al., 2010). The seasonal variation of $\AA \mathrm{E}$ is small as the major source during the year is industrial pollutant. On the other hand, the AOTs over Western Europe exhibit a significant seasonal variation, which is increasing from spring to summer and decreasing from 

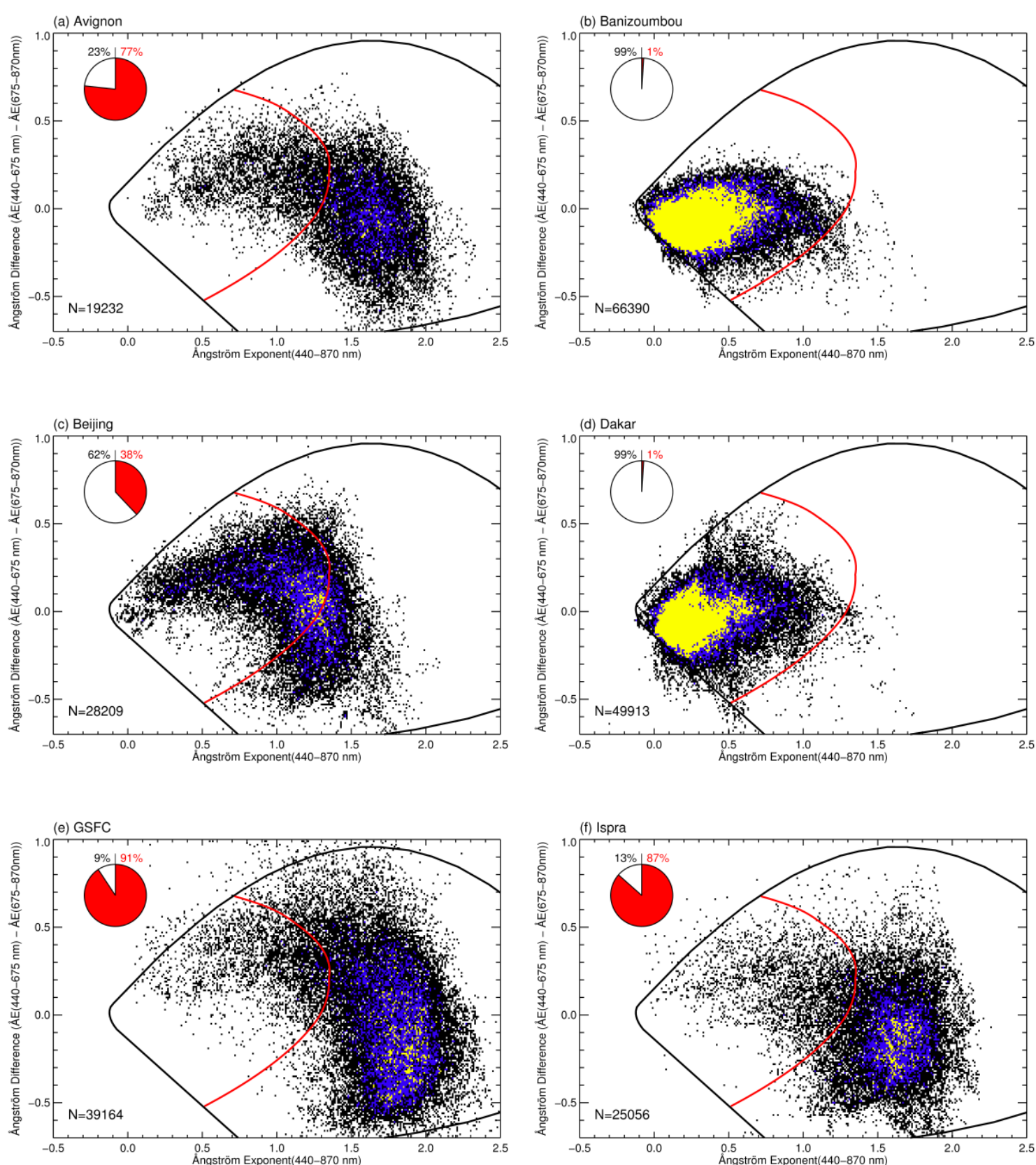

Fig. 6. Applications of the classification method to the AERONET level 2.0 datasets separated into two aerosol types as fine- and coarse-mode dominant aerosols at the several stations. The circle diagram on the upper-left hand means the percentage of coarse (black) and fine-mode (red) dominant aerosols to total observations $(N)$. To avoid large errors in Ångström exponent and its difference from low AOTs, only AERONET level 2.0 data with AOT $(440 \mathrm{~nm})>0.15$ were used.

autumn to winter (Fig. 7). Basically, the AOT depends on the aerosol extinction coefficient (influenced, e.g. by aerosol types, emission intensity, and relative humidity) and boundary layer height. Especially industrial pollutants composed of sulphur are enhanced during summer due to stronger solar radiation (Marmer et al., 2007; Karnieli et al., 2009). Additionally, less removal process (e.g. rain/monsoon) as well as a higher boundary layer height causes higher AOTs over Eu- rope in summer (Gerasopoulos et al., 2003; Bergamo et al., 2008; Venzac et al., 2009). The weighted AOT trends over both stations are insignificant or decreasing $\left(+0.98 \% \mathrm{yr}^{-1}\right.$ at Avignon and $-2.30 \% \mathrm{yr}^{-1}$ at Ispra), most likely due to strict environmental regulations for mitigating climate change and improving air quality (Smith et al., 2001; Streets et al., 2006; Zhao et al., 2008). These tendencies are confirmed once again in negligable or decreasing FdAOT trends at the 

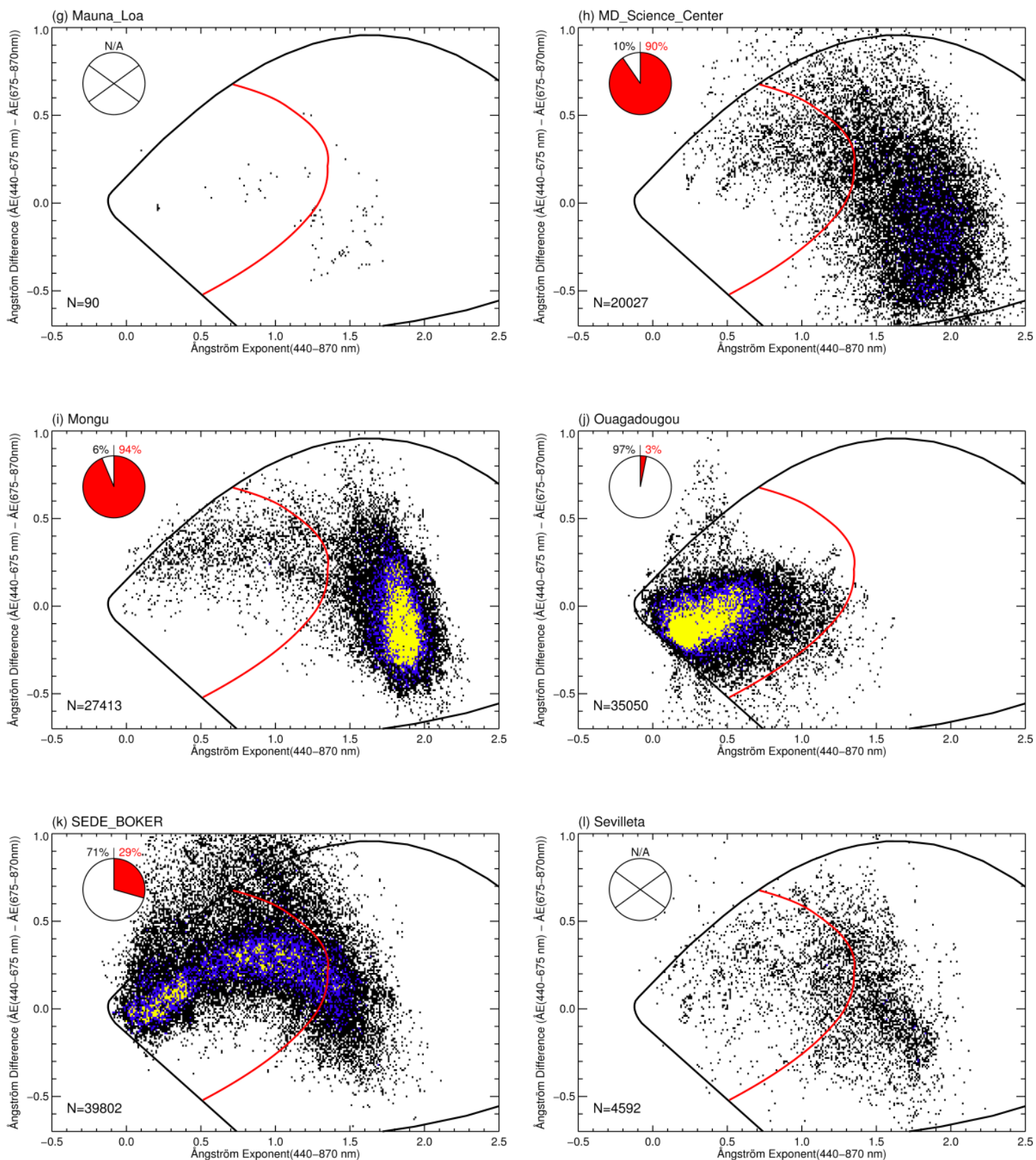

Fig. 6. Continued.

stations $\left(+0.25 \% \mathrm{yr}^{-1}\right.$ at Avignon and $-2.29 \% \mathrm{yr}^{-1}$ at Ispra as shown in Fig. 9).

\subsection{West Africa}

Mineral dust mainly from the Saharan and Sahel regions is the most abundant aerosol type year-round, influencing Banizoumbou, Dakar, and Ouagadougou stations over West Africa (Prospero and Lamb, 2003; Washington and Todd, 2005; Moulin and Chiapello, 2004; Reeves et al., 2010). Besides, biomass burning is frequently advected by the West
African monsoon in summer from Central Africa (Hao and Liu, 1994) and emitted from agricultural activity during the dry season (December-February) in West Africa (Johnson et al., 2008a). The complex vertical distribution between mineral dust and biomass burning is a difficult condition to assess the shortwave radiative effects in a difficult way (Johnson et al., 2008b). Additionally, low AOT might occur as a result of efficient wet removal of aerosol particles due to heavy precipitation (Reeves et al., 2010; Huang et al., 2009). In Fig. 7, series of these phenomena over West Africa represent the seasonal pattern in $\AA \mathrm{E}$ and AOT. Insignificant or 

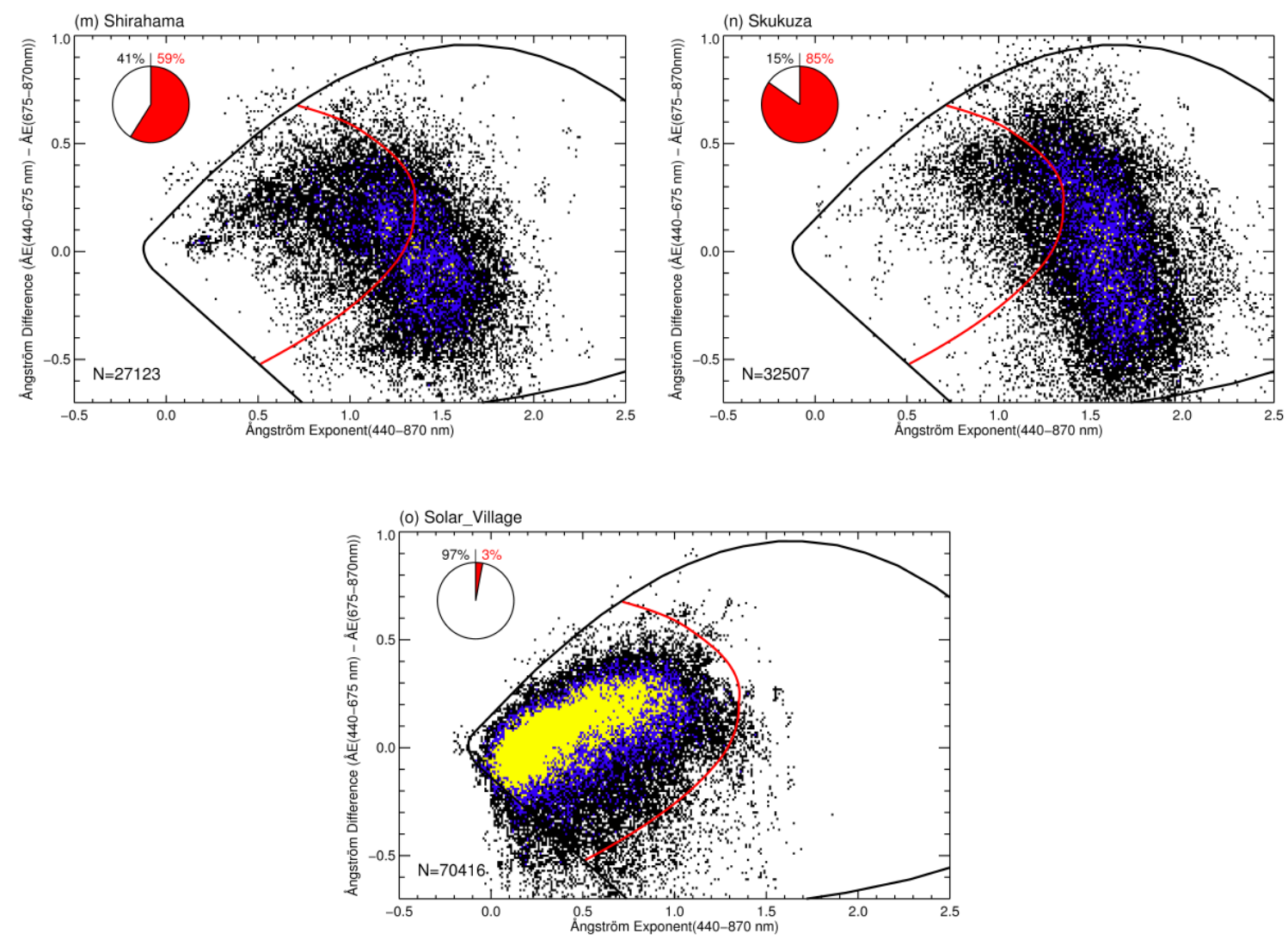

Fig. 6. Continued.

decreasing trends of dust aerosol due to decreasing dust activity (Evan et al., 2007) are observed over most stations in West Africa $\left(+0.22 \% \mathrm{yr}^{-1}\right.$ at Banizoumbou, $-1.56 \% \mathrm{yr}^{-1}$ at Dakar, and $-1.95 \% \mathrm{yr}^{-1}$ at Ouagadougou), which is consistent with the results from the Global Aerosol Climatology Project (GACP) data (Mishchenko and Geogdzhayev, 2007; Mishchenko et al., 2007), in situ measurement (Chiapello et al., 2005), AVHRR (Zhao et al., 2008), and TOMS observations (Chiapello and Moulin, 2002). The weighted trends of $\AA \mathrm{E}$ and AOT at Dakar and Ouagadougou are different compared to unweighted trends due to frequent cloud disturbance. CdAOT trends over West Africa $\left(+0.28 \% \mathrm{yr}^{-1}\right.$ at Banizoumbou, $-1.56 \% \mathrm{yr}^{-1}$ at Dakar, and $-1.88 \% \mathrm{yr}^{-1}$ at Ouagadougou in Fig. 9) are generally similar with AOT trends.

\subsection{South Africa}

$\AA ̊ A$ as well as AOT over the stations in South Africa (i.e. Mongu and Skukuza) exhibit a strong seasonality due to pronounced wet and dry seasons (see Fig. 7), and the presence of biomass burning aerosol (Tyson, 1986; Swap et al., 1996). Frequent occurrence of burning activity in warm and dry seasons leads to a large biomass burning (Eck et al., 2001). The regions close to Skukuza (where are less suscep- tible to local burning) are also influenced by aerosol mixtures with fossil fuel burning, industrial pollutant, and Aeolian coarse mode types (Eck et al., 2003). The cloud uncertainty in the trend analysis is insignificant because the biomass burning generally happens before the beginning of the rain seasons. A noticeable increase of AOT at Mongu $\left(+2.26 \% \mathrm{yr}^{-1}\right)$ is most likely affected by biomass burning (Mishchenko and Geogdzhayev, 2007; Zhao et al., 2008). Accordingly, positive trends of FdAOT over South Africa are observed $\left(+1.89 \% \mathrm{yr}^{-1}\right.$ at Mongu and $+0.55 \% \mathrm{yr}^{-1}$ at Skukuza) in Fig. 9.

\subsection{Middle East}

The stations SEDE_BOKER and Solar_Village are located within the Middle East and provide a long record of measurements because of stable and clear-sky weather conditions (Basart et al., 2009). In this region, aerosol size and composition are dominated by fine-mode pollution emitted from the regional petroleum industry (Zhao et al., 2008; Basart et al., 2009) and mineral dust transported from the Anatolian plateau, Sahara, Negev, and Arabian deserts (Kubilay et al., 2003; Derimian et al., 2006; Sabbah et al., 2006; Smirnov et al., 2002; Tafuro et al., 2006). The latter explains the clear periodical pattern of $\AA \mathrm{E}$ and AOT seen in Fig. 7. The AOT 
Table 2. Bimodal lognormal volume size distribution $\left(\frac{\mathrm{d} V(r)}{\mathrm{d} \ln r}\right)$ parameters and refractive indices (Schuster et al., 2006) used to compute ÅE

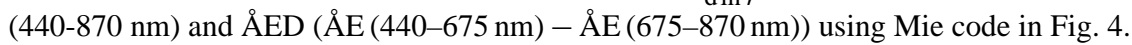

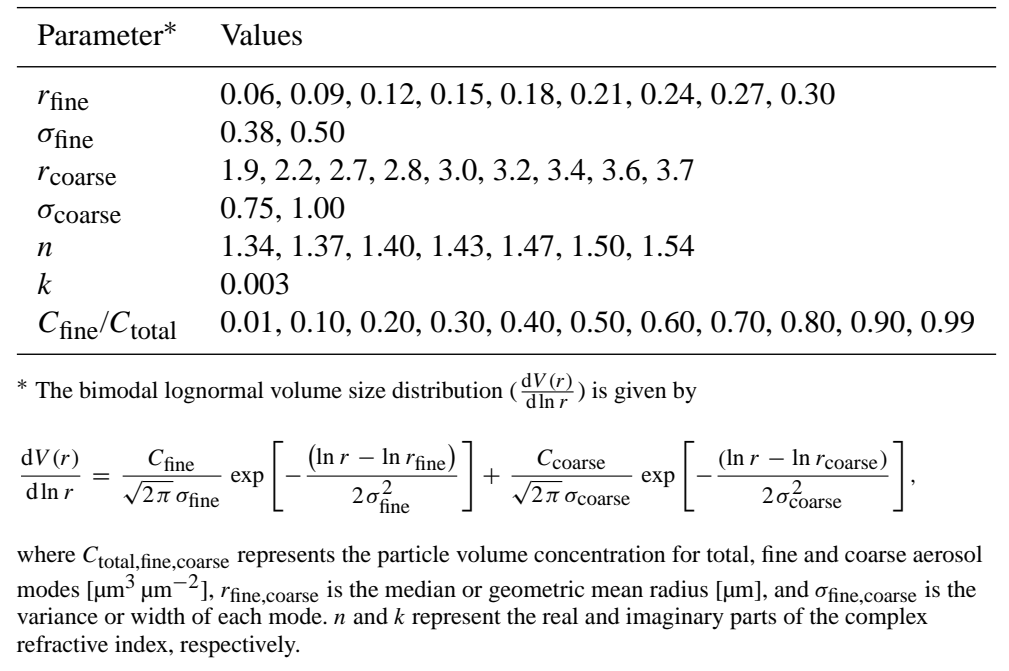

over SEDE_BOKER tend to decrease $\left(-2.16 \% \mathrm{yr}^{-1}\right)$ due to a decrease in coarse particles $\left(-2.89 \% \mathrm{yr}^{-1}\right.$ for CdAOT in Fig. 9), while AOT over Solar_Village show a strong increase $\left(+3.29 \% \mathrm{yr}^{-1}\right)$ in the weighted trend probably related to an increase of mineral dust $\left(+3.37 \% \mathrm{yr}^{-1}\right.$ for CdAOT) and change of atmospheric conditions (e.g. increase of wind speed and relative humidity) (Sabbah and Hasan, 2008). Interestingly, there are clear differences between the unweighted and weighted trends at both stations due to a large standard error caused by high variability of $\AA \mathrm{E}$ and AOT as well as a small number of observations due to low cloud cover. The weighted FdAOT trends of SEDE_BOKER and Solar_Village are insignificant $\left(+0.75 \%\right.$ and $-0.10 \% \mathrm{yr}^{-1}$, respectively, as seen in Fig. 9).

\subsection{East Asia}

Many emerging economies are found in East Asia, where, as a consequence, large amounts of anthropogenic aerosols are emitted. Additionally, mineral dust from the deserts in Mongolia and in Western and Northern China (mainly the Taklimakan and Badain Juran deserts) contributes around $70 \%$ of the total dust emissions in mid-latitude regions. Rapid desertification caused by climatic variation and human activities additionally increases the aerosol burden due to mineral dust transport (Zhang et al., 2003). ÅE and AOT at Beijing in Fig. 7 exhibit very clear seasonal cycles, which have been explained by the complex combination of natural and anthropogenic aerosols, stagnant synoptic meteorological patterns, secondary aerosol formation, and hygroscopic growth (Kotchenruther et al., 1999; Dubovik et al., 2002a; Kim et al., 2007). Because of industrialization, urbanization, and desertification over East Asia in the last twenty years, the aerosol loading over Beijing increased rapidly and the magnitude of the weighted trend is $+4.59 \% \mathrm{yr}^{-1}$. This trend is consistent with many previous studies (Streets et al., 2000, 2003, 2006; Smith et al., 2001, 2003; Massie et al., 2004; Mishchenko and Geogdzhayev, 2007; Zhao et al., 2008). The weighted trend is larger than the unweighted one $\left(+1.06 \% \mathrm{yr}^{-1}\right)$, as there are smaller weighting factors due to frequent cloud disturbance during summer in Beijing. Such increase is also observed in both aerosol types and more pronounced for weighted trends of CdAOT and FdAOT with increases of $+7.27 \%$ and $+6.23 \% \mathrm{yr}^{-1}$, respectively. Shirahama is in the middle of Japan, far-off large cities, facing the Pacific Ocean (Mukai et al., 2006). Hence, maritime aerosol is predominant, but there are occurrences of mineral dust and/or industrial aerosol transported by strong westerly winds from China (Sano et al., 2003; Mukai et al., 2005). The seasonal cycles of $\AA \mathrm{E}$ and AOT in Fig. 7 are similar to those at Beijing due to similar meteorological conditions and aerosol sources. The upward trend of AOT is small $\left(+0.44 \% \mathrm{yr}^{-1}\right)$, while ÅE increases $\left(+2.07 \% \mathrm{yr}^{-1}\right)$ clearly. Due to comparatively small number of observations over Shirahama, only slight differences between weighted and unweighted trends of $\AA \mathrm{E}$ and AOT are observed all year round (see Fig. 2). The magnitudes of the CdAOT and FdAOT trends are, after classification, $+1.81 \%$ and $-0.03 \% \mathrm{yr}^{-1}$, respectively.

\subsection{North America}

The stations GSFC and MD_Science_Center are located on urban and built-up land, while Sevilleta is positioned at shrub land over North America (Liu et al., 2004). Main aerosol type measured at GSFC and MD_Science_Center is urbanindustrial pollution from vehicles and industries. The seasonal cycles of $\AA \mathrm{E}$ and AOT in Fig. 7 demonstrate that the variabilities are strongly dependent on the combination 


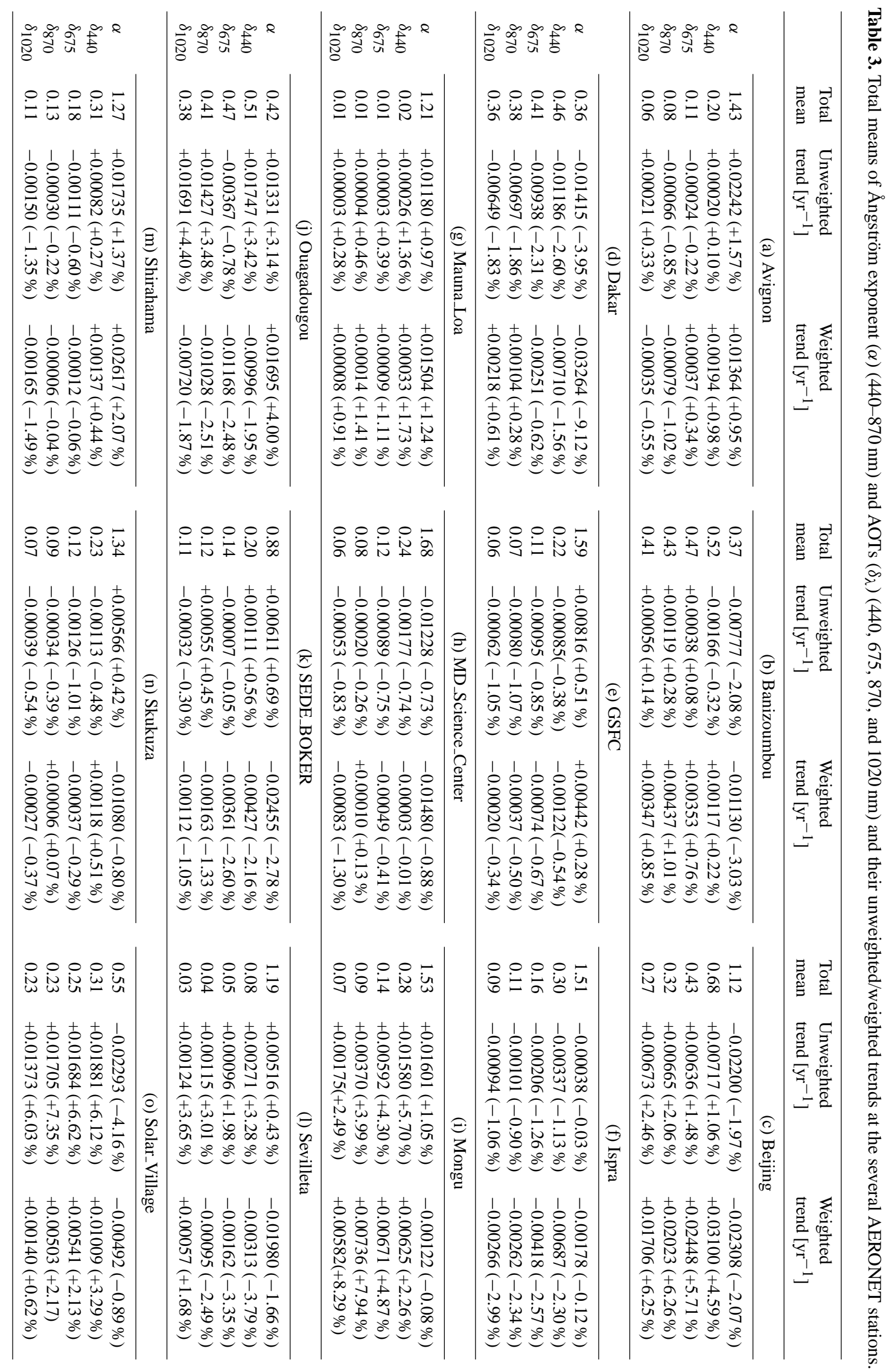


Table 4. Total means of CdAOT and FdAOT (440, 675, 870, and $1020 \mathrm{~nm})$ and their unweighted/weighted trends at the several AERONET stations except (g) Mauna_Loa and (1) Sevilleta where the classification is non-applicable.

\begin{tabular}{|c|c|c|c|c|c|c|}
\hline & \multicolumn{3}{|c|}{ Coarse-mode dominant AOT (CdAOT) } & \multicolumn{3}{|c|}{ Fine-mode dominant AOT (FdAOT) } \\
\hline & $\begin{array}{l}\text { Total } \\
\text { mean }\end{array}$ & $\begin{array}{l}\text { Unweighted } \\
\text { trend }\left[\mathrm{yr}^{-1}\right]\end{array}$ & $\begin{array}{l}\text { Weighted } \\
\text { trend }\left[\mathrm{yr}^{-1}\right]\end{array}$ & $\begin{array}{l}\text { Total } \\
\text { mean }\end{array}$ & $\begin{array}{l}\text { Unweighted } \\
\text { trend }\left[\mathrm{yr}^{-1}\right]\end{array}$ & $\begin{array}{l}\text { Weighted } \\
\text { trend }\left[\mathrm{yr}^{-1}\right]\end{array}$ \\
\hline & \multicolumn{6}{|c|}{ (a) Avignon } \\
\hline$\delta_{440}$ & 0.14 & $+0.00374(+2.59 \%)$ & $+0.00323(+2.23 \%)$ & 0.18 & $-0.00032(-0.18 \%)$ & $+0.00047(+0.25 \%)$ \\
\hline$\delta_{675}$ & 0.09 & $+0.00211(+2.48 \%)$ & $+0.00130(+1.53 \%)$ & 0.09 & $-0.00062(-0.66 \%)$ & $-0.00028(-0.30 \%)$ \\
\hline$\delta_{870}$ & 0.07 & $+0.00125(+1.87 \%)$ & $+0.00056(+0.83 \%)$ & 0.06 & $-0.00098(-1.51 \%)$ & $-0.00119(-1.84 \%)$ \\
\hline \multirow[t]{2}{*}{$\delta_{1020}$} & 0.06 & $+0.00187(+3.19 \%)$ & $+0.00102(+1.75 \%)$ & 0.05 & $-0.00009(-0.18 \%)$ & $-0.00079(-1.54 \%)$ \\
\hline & \multicolumn{6}{|c|}{ (b) Banizoumbou* } \\
\hline$\delta_{440}$ & 0.52 & $-0.00160(-0.31 \%)$ & $+0.00147(+0.28 \%)$ & 0.14 & $-0.00767(-5.50 \%)$ & $+0.00287(+2.05 \%)$ \\
\hline$\delta_{675}$ & 0.47 & $+0.00042(+0.09 \%)$ & $+0.00382(+0.81 \%)$ & 0.10 & $-0.00420(-4.23 \%)$ & $+0.00256(+2.57 \%)$ \\
\hline$\delta_{870}$ & 0.43 & $+0.00122(+0.28 \%)$ & $+0.00467(+1.08 \%)$ & 0.08 & $-0.00290(-3.60 \%)$ & $+0.00090(+1.12 \%)$ \\
\hline \multirow[t]{2}{*}{$\delta_{1020}$} & 0.41 & $+0.00059(+0.14 \%)$ & $+0.00378(+0.92 \%)$ & 0.07 & $-0.00347(-4.73 \%)$ & $-0.00021(-0.28 \%)$ \\
\hline & \multicolumn{6}{|c|}{ (c) Beijing } \\
\hline$\delta_{440}$ & 0.47 & $-0.00391(-0.84 \%)$ & $+0.03398(+7.27 \%)$ & 0.72 & $+0.02673(+3.74 \%)$ & $+0.04455(+6.23 \%)$ \\
\hline$\delta_{675}$ & 0.32 & $-0.00231(-0.73 \%)$ & $+0.02245(+7.11 \%)$ & 0.43 & $+0.01856(+4.30 \%)$ & $+0.02199(+5.10 \%)$ \\
\hline$\delta_{870}$ & 0.26 & $-0.00081(-0.32 \%)$ & $+0.01749(+6.84 \%)$ & 0.30 & $+0.01409(+4.62 \%)$ & $+0.01530(+5.02 \%)$ \\
\hline \multirow[t]{2}{*}{$\delta_{1020}$} & 0.23 & $-0.00026(-0.11 \%)$ & $+0.01485(+6.52 \%)$ & 0.25 & $+0.01167(+4.76 \%)$ & $+0.01135(+4.63 \%)$ \\
\hline & \multicolumn{6}{|c|}{ (d) Dakar* } \\
\hline$\delta_{440}$ & 0.46 & $-0.01283(-2.81 \%)$ & $-0.00710(-1.56 \%)$ & 0.17 & $-0.01210(-7.29 \%)$ & $-0.00723(-4.36 \%)$ \\
\hline$\delta_{675}$ & 0.41 & $-0.01049(-2.58 \%)$ & $-0.00258(-0.63 \%)$ & 0.12 & $-0.00880(-7.23 \%)$ & $-0.00511(-4.20 \%)$ \\
\hline$\delta_{870}$ & 0.38 & $-0.00815(-2.16 \%)$ & $+0.00086(+0.23 \%)$ & 0.10 & $-0.00528(-5.27 \%)$ & $-0.00398(-3.98 \%)$ \\
\hline \multirow[t]{2}{*}{$\delta_{1020}$} & 0.36 & $-0.00767(-2.15 \%)$ & $+0.00198(+0.56 \%)$ & 0.09 & $-0.00483(-5.35 \%)$ & $-0.00378(-4.19 \%)$ \\
\hline & \multicolumn{6}{|c|}{ (e) GSFC } \\
\hline$\delta_{440}$ & 0.13 & $-0.00365(-2.73 \%)$ & $-0.00020(-0.15 \%)$ & 0.22 & $-0.00031(-0.14 \%)$ & $-0.00116(-0.52 \%)$ \\
\hline$\delta_{675}$ & 0.07 & $-0.00324(-4.38 \%)$ & $-0.00009(-0.12 \%)$ & 0.11 & $-0.00043(-0.40 \%)$ & $-0.00081(-0.75 \%)$ \\
\hline$\delta_{870}$ & 0.06 & $-0.00289(-4.97 \%)$ & $+0.00014(+0.24 \%)$ & 0.07 & $-0.00028(-0.40 \%)$ & $-0.00046(-0.64 \%)$ \\
\hline \multirow[t]{2}{*}{$\delta_{1020}$} & 0.05 & $-0.00226(-5.27 \%)$ & $+0.00031(+0.62 \%)$ & 0.05 & $-0.00010(-0.18 \%)$ & $-0.00028(-0.52 \%)$ \\
\hline & \multicolumn{6}{|c|}{ (f) Ispra } \\
\hline$\delta_{440}$ & 0.16 & $+0.00368(+2.26 \%)$ & $-0.00193(-1.18 \%)$ & 0.29 & $-0.00343(-1.19 \%)$ & $-0.00659(-2.29 \%)$ \\
\hline$\delta_{675}$ & 0.10 & $+0.00153(+1.56 \%)$ & $-0.00266(-2.69 \%)$ & 0.15 & $-0.00198(-1.30 \%)$ & $-0.00423(-2.78 \%)$ \\
\hline$\delta_{870}$ & 0.08 & $+0.00136(+1.76 \%)$ & $-0.00155(-2.01 \%)$ & 0.10 & $-0.00088(-0.87 \%)$ & $-0.00228(-2.25 \%)$ \\
\hline \multirow[t]{2}{*}{$\delta_{1020}$} & 0.07 & $+0.00099(+1.46 \%)$ & $-0.00156(-2.30 \%)$ & 0.08 & $-0.00076(-0.97 \%)$ & $-0.00192(-2.44 \%)$ \\
\hline & \multicolumn{6}{|c|}{ (h) MD_Science_Center } \\
\hline$\delta_{440}$ & 0.14 & $-0.00151(-1.08 \%)$ & $+0.00131(+0.94 \%)$ & 0.24 & $-0.00147(-0.61 \%)$ & $-0.00003(-0.01 \%)$ \\
\hline$\delta_{675}$ & 0.08 & $-0.00121(-1.60 \%)$ & $+0.00050(+0.66 \%)$ & 0.12 & $-0.00061(-0.53 \%)$ & $+0.00022(+0.19 \%)$ \\
\hline$\delta_{870}$ & 0.06 & $-0.00065(-1.14 \%)$ & $+0.00096(+1.69 \%)$ & 0.08 & $+0.00007(+0.09 \%)$ & $+0.00077(+1.03 \%)$ \\
\hline \multirow[t]{2}{*}{$\delta_{1020}$} & 0.05 & $-0.00107(-2.06 \%)$ & $+0.00003(+0.06 \%)$ & 0.06 & $-0.00027(-0.45 \%)$ & $-0.00023(-0.38 \%)$ \\
\hline & \multicolumn{6}{|c|}{ (i) Mongu } \\
\hline$\delta_{440}$ & 0.18 & $-0.01204(-6.57 \%)$ & $-0.00055(-0.30 \%)$ & 0.27 & $+0.01689(+6.26 \%)$ & $+0.00509(+1.89 \%)$ \\
\hline$\delta_{675}$ & 0.11 & $-0.00797(-7.39 \%)$ & $+0.00036(+0.33 \%)$ & 0.13 & $+0.00667(+5.12 \%)$ & $+0.00552(+4.23 \%)$ \\
\hline$\delta_{870}$ & 0.09 & $-0.00559(-6.54 \%)$ & $+0.00141(+1.65 \%)$ & 0.09 & $+0.00439(+5.15 \%)$ & $+0.00603(+7.08 \%)$ \\
\hline \multirow[t]{2}{*}{$\delta_{1020}$} & 0.07 & $-0.00571(-7.91 \%)$ & $+0.00107(+1.48 \%)$ & 0.06 & $+0.00245(+3.92 \%)$ & $+0.00418(+6.69 \%)$ \\
\hline & \multicolumn{6}{|c|}{ (j) Ouagadougou* } \\
\hline$\delta_{440}$ & 0.51 & $+0.01705(+3.32 \%)$ & $-0.00964(-1.88 \%)$ & 0.22 & $-0.02445(-11.30 \%)$ & $+0.00179(+0.83 \%)$ \\
\hline$\delta_{675}$ & 0.48 & $-0.01380(-2.85 \%)$ & $-0.00043(-0.09 \%)$ & 0.19 & $-0.05651(-29.18 \%)$ & $-0.00065(-0.34 \%)$ \\
\hline$\delta_{870}$ & 0.41 & $+0.01405(+3.41 \%)$ & $-0.00997(-2.42 \%)$ & 0.14 & $-0.03348(-24.50 \%)$ & $-0.00240(-1.76 \%)$ \\
\hline$\delta_{1020}$ & 0.39 & $+0.01663(+4.30 \%)$ & $-0.00726(-1.88 \%)$ & 0.12 & $-0.02768(-23.17 \%)$ & $-0.00109(-0.91 \%)$ \\
\hline
\end{tabular}


Table 4. Continued.

\begin{tabular}{|c|c|c|c|c|c|c|}
\hline & \multicolumn{3}{|c|}{ Coarse-mode dominant AOT (CdAOT) } & \multicolumn{3}{|c|}{ Fine-mode dominant AOT (FdAOT) } \\
\hline & $\begin{array}{l}\text { Total } \\
\text { mean }\end{array}$ & $\begin{array}{l}\text { Unweighted } \\
\text { trend }\left[\mathrm{yr}^{-1}\right]\end{array}$ & $\begin{array}{l}\text { Weighted } \\
\text { trend }\left[\mathrm{yr}^{-1}\right]\end{array}$ & $\begin{array}{l}\text { Total } \\
\text { mean }\end{array}$ & $\begin{array}{l}\text { Unweighted } \\
\text { trend }\left[\mathrm{yr}^{-1}\right]\end{array}$ & $\begin{array}{l}\text { Weighted } \\
\text { trend }\left[\mathrm{yr}^{-1}\right]\end{array}$ \\
\hline & \multicolumn{6}{|c|}{ (k) SEDE_BOKER } \\
\hline$\delta_{440}$ & 0.19 & $+0.00156(+0.81 \%)$ & $-0.00560(-2.89 \%)$ & 0.14 & $+0.00190(+1.38 \%)$ & $+0.00104(+0.75 \%)$ \\
\hline$\delta_{675}$ & 0.14 & $+0.00052(+0.37 \%)$ & $-0.00528(-3.77 \%)$ & 0.08 & $+0.00104(+1.27 \%)$ & $+0.00016(+0.20 \%)$ \\
\hline$\delta_{870}$ & 0.13 & $+0.00112(+0.89 \%)$ & $-0.00383(-3.04 \%)$ & 0.07 & $+0.00181(+2.64 \%)$ & $+0.00114(+1.67 \%)$ \\
\hline \multirow[t]{2}{*}{$\delta_{1020}$} & 0.11 & $+0.00020(+0.18 \%)$ & $-0.00350(-3.16 \%)$ & 0.05 & $+0.00101(+1.86 \%)$ & $+0.00108(+2.00 \%)$ \\
\hline & \multicolumn{6}{|c|}{ (m) Shirahama } \\
\hline$\delta_{440}$ & 0.23 & $+0.00706(+3.05 \%)$ & $+0.00420(+1.81 \%)$ & 0.31 & $+0.00046(+0.15 \%)$ & $-0.00009-0.03 \%)$ \\
\hline$\delta_{675}$ & 0.15 & $+0.00294(+1.99 \%)$ & $+0.00233(+1.58 \%)$ & 0.17 & $-0.00163(-0.95 \%)$ & $-0.00089(-0.52 \%)$ \\
\hline$\delta_{870}$ & 0.12 & $+0.00253(+2.13 \%)$ & $+0.00219(+1.84 \%)$ & 0.12 & $-0.00073(-0.61 \%)$ & $-0.00058(-0.48 \%)$ \\
\hline \multirow[t]{2}{*}{$\delta_{1020}$} & 0.10 & $+0.00075(+0.73 \%)$ & $+0.00059(+0.58 \%)$ & 0.09 & $-0.00183(-1.96 \%)$ & $-0.00193(-2.06 \%)$ \\
\hline & \multicolumn{6}{|c|}{ (n) Skukuza } \\
\hline$\delta_{440}$ & 0.13 & $-0.00111(-0.83 \%)$ & $-0.00045(-0.34 \%)$ & 0.23 & $-0.00083(-0.36 \%)$ & $+0.00127(+0.55 \%)$ \\
\hline$\delta_{675}$ & 0.08 & $-0.00183(-2.16 \%)$ & $-0.00141(-1.67 \%)$ & 0.12 & $-0.00104(-0.86 \%)$ & $-0.00033(-0.27 \%)$ \\
\hline$\delta_{870}$ & 0.07 & $-0.00128(-1.95 \%)$ & $-0.00024(-0.37 \%)$ & 0.08 & $-0.00014(-0.17 \%)$ & $-0.00004(-0.05 \%)$ \\
\hline \multirow[t]{2}{*}{$\delta_{1020}$} & 0.06 & $-0.00152(-2.58 \%)$ & $-0.00049(-0.84 \%)$ & 0.07 & $-0.00020(-0.29 \%)$ & $-0.00036(-0.53 \%)$ \\
\hline & \multicolumn{6}{|c|}{ (o) Solar_Village* } \\
\hline$\delta_{440}$ & 0.31 & $+0.01848(+6.00 \%)$ & $+0.01037(+3.37 \%)$ & 0.13 & $-0.00487(-3.72 \%)$ & $-0.00013(-0.10 \%)$ \\
\hline$\delta_{675}$ & 0.26 & $+0.01649(+6.46 \%)$ & $+0.00586(+2.29 \%)$ & 0.10 & $-0.00431(-4.30 \%)$ & $-0.00016(-0.16 \%)$ \\
\hline$\delta_{870}$ & 0.23 & $+0.01657(+7.11 \%)$ & $+0.00524(+2.25 \%)$ & 0.08 & $-0.00208(-2.46 \%)$ & $+0.00064(+0.76 \%)$ \\
\hline$\delta_{1020}$ & 0.23 & $+0.01337(+5.85 \%)$ & $+0.00195(+0.85 \%))$ & 0.09 & $-0.00553(-6.30 \%)$ & $-0.00155(-1.77 \%)$ \\
\hline
\end{tabular}

* Trend analysis of FdAOTs represented in italic type might be insignificant because of incomplete yearly data sets.

of natural and anthropogenic aerosols, fuel types, emission characteristic, relative humidity, boundary layer depth, and scavenging by precipitation (Glen et al., 1996; Chen et al., 2001; Dubovik et al., 2002a; Andronache, 2004). The negative trends of AOT $\left(-0.54 \%\right.$ and $-0.01 \% \mathrm{yr}^{-1}$ at GSFC and MD_Science_Center) are consistent with the decrease of industrial emissions in the United States of America (Smith et al., 2001; Streets et al., 2006; Zhao et al., 2008). Sevilleta station measures a relatively small aerosol loading for the considered time span. The weighted trends are strongly negative $\left(-1.66 \% \mathrm{yr}^{-1}\right.$ for $\AA \mathrm{E}$ and $-3.79 \% \mathrm{yr}^{-1}$ for AOT), clearly different from the unweighted ones $\left(+0.43 \% \mathrm{yr}^{-1}\right.$ for $\AA \mathrm{E}$ and $+3.28 \% \mathrm{yr}^{-1}$ for AOT). In most cases of monthly averaged AOT at Sevilleta, the values are lower than 0.15 , so that the classification for the trend analysis was not applied to data of this station. The majority of retrieved aerosol type at GSFC and MD_Science_Center is fine-mode, and the weighted trends of FdAOT are $-0.52 \%$ and $-0.01 \% \mathrm{yr}^{-1}$, respectively (see Fig. 9).

\subsection{Mauna_Loa}

Aerosols measured at Mauna_Loa (alt. $\sim 3397 \mathrm{~m}$ ) in the Pacific are representative for free tropospheric aerosols. However, the station in the tropical mid-Pacific is also under some influence of long-range transport (over 6000 to $8000 \mathrm{~km}$ ) of Asian mineral dust and pollution in spring (Perry et al., 1999; Eck et al., 2005). The free troposphere is characterized by being almost cloud-free in the subsiding branch of the Hadley cell as well as a pathway for long-distance transport of aerosols (Garstang and Fitzjarrald, 1999; Schmeissner et al., 2011). In most cases, free tropospheric AOT $(440 \mathrm{~nm})$ does not exceed values of 0.05 except when affected by volcano eruption or transported mineral dust and pollution. Therefore, it is difficult to analyze size and type, as the error in $\AA \mathrm{E}$ from low AOTs could be significant (Gobbi et al., 2007; Kaskaoutis et al., 2011a). The main factors affecting the seasonal pattern of AOT are most likely long-range transported aerosols and seasonal meteorological conditions; the AOT trend for this station is positive $\left(+1.73 \% \mathrm{yr}^{-1}\right)$. In addition, in order to investigate the trends in stratospheric or free tropospheric aerosols, the AOT data from March to May were excluded, and we found that AOTs at $440 \mathrm{~nm}$ are increasing by $+0.00047(+3.03 \%)$ for unweighted and $+0.00049(+3.16 \%)$ per year for weighted trend analysis. However, these increasing tendencies at Mauna_Loa might be insignificant because most of AOTs $(440 \mathrm{~nm})$ are close to the observation uncertainty $( \pm 0.01)$ (Eck et al., 1999). 

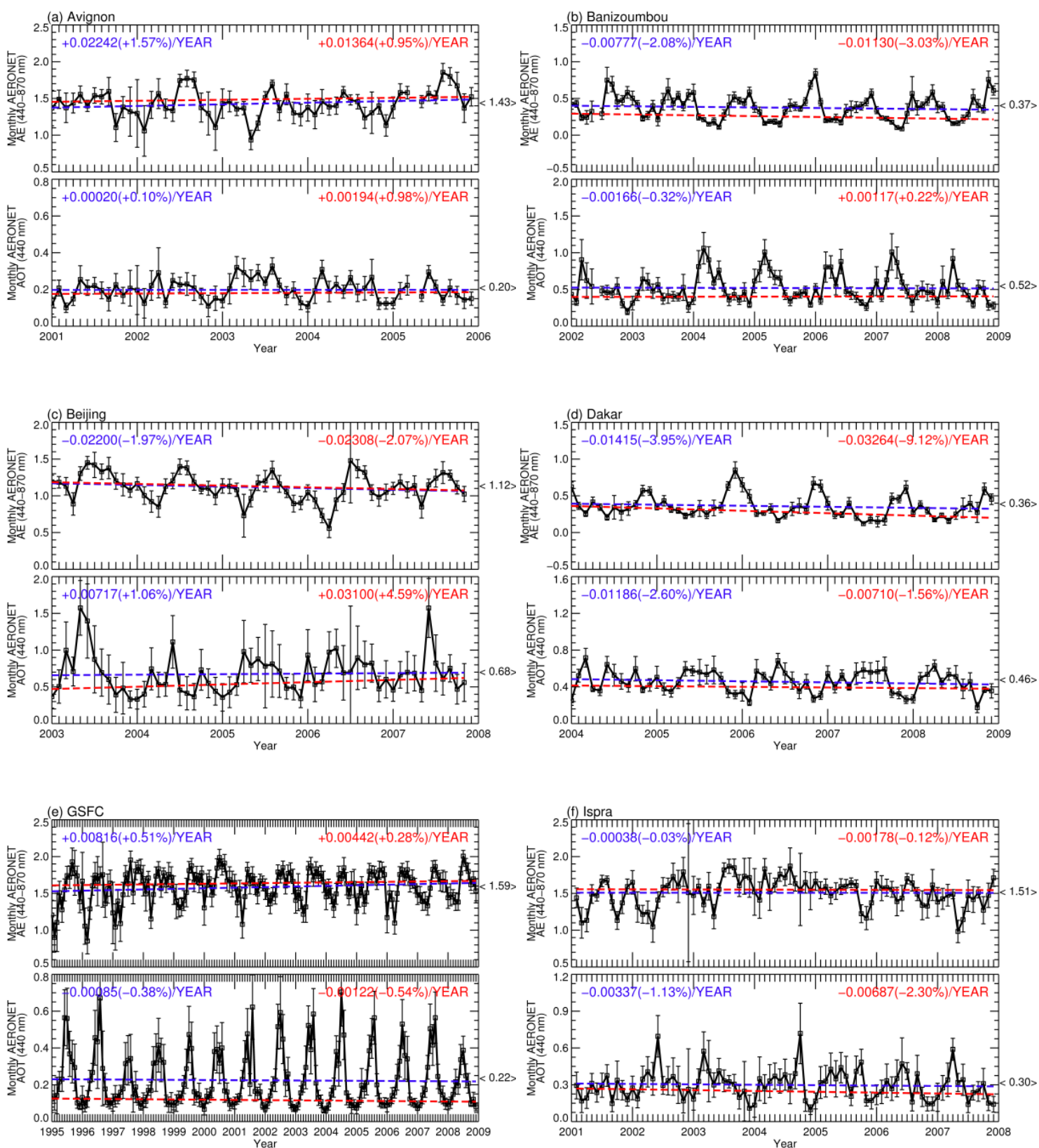

Fig. 7. Unweighted (blue one on the left upper part) and weighted (red one of the richt upper part) trends of Ångström Exponent (440-870 nm) $(\alpha)$ amd AOT $(440 \mathrm{~nm})\left(\delta_{440}\right)$ at the several AERONET stations. The total means of $\alpha$ and $\delta_{440}$ (black one enclosed with parentheses) are shown on right vertical axis. The error bar means the 10 times of the standard error, which are used for the weighted trend analysis.

\section{Summary and conclusion}

In this study, long-term trends of the level 2.0 Ångström exponent (ÅE) (440-870 nm), aerosol optical thickness (AOT), and coarse- and fine-mode dominant AOTs (CdAOT and FdAOT) $(440,675,870$, and $1020 \mathrm{~nm})$ observed at several AERONET stations have been analyzed. Firstly, suitable AERONET stations providing sufficiently long-term data series were chosen in order to make a meaningful trend analysis. Unfortunately, the research periods were different for each AERONET station due to the different observation history and condition (see Table 1 and Fig. 1). Weighted trends were derived utilizing monthly standard deviation and number of observations $\left(n_{t}\right)$ providing an estimate of trend uncertainty (primarily) due to cloud disturbance. For example, if there was a high variability of aerosol loading for a small $n_{t}$, then significant difference between unweighted and weighted trends was observed.

In general, cloud-free aerosol trends in this study are consistent with results from other papers (Zhao et al., 2008; 

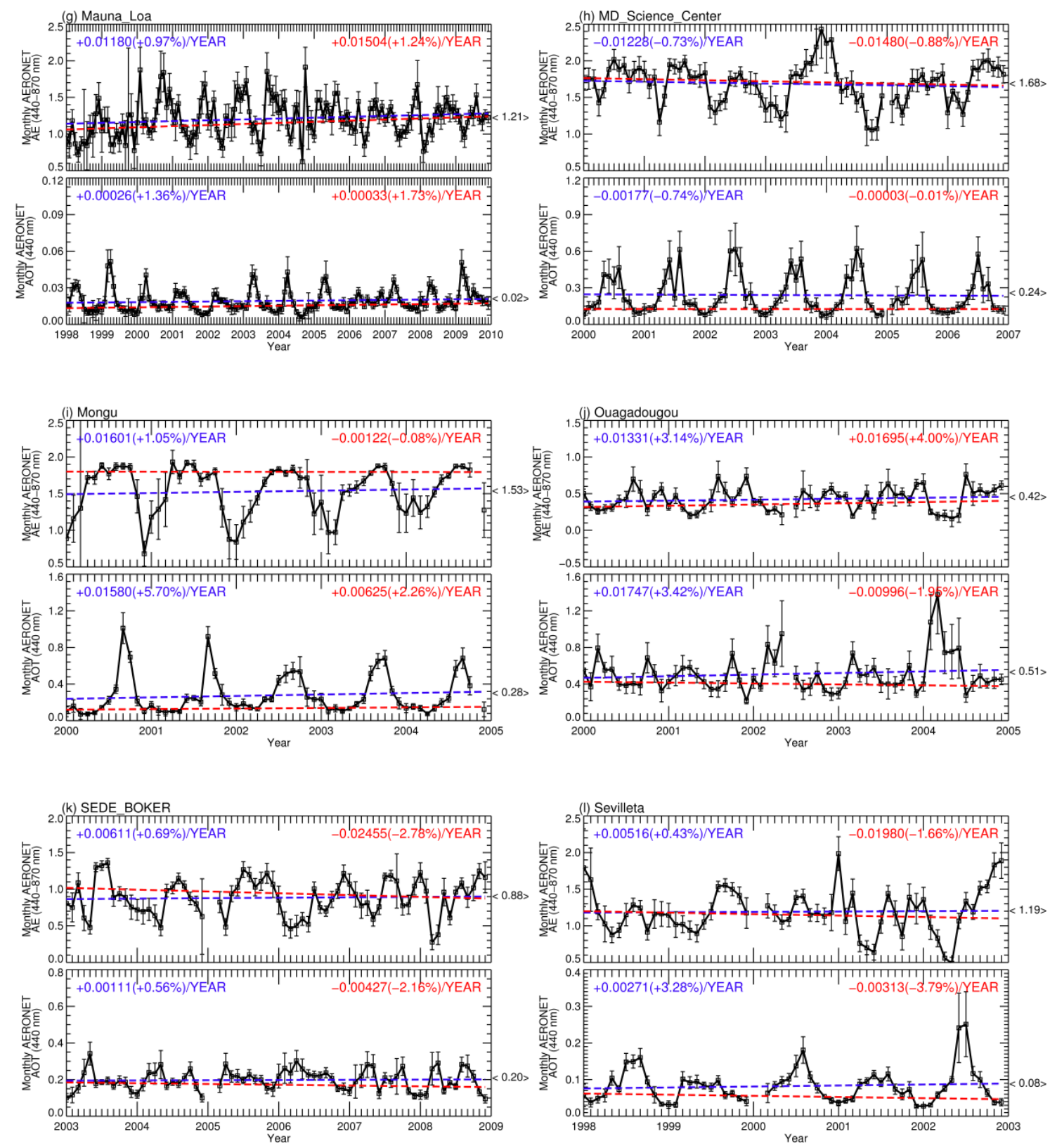

Fig. 7. Continued.

Karnieli et al., 2009; Yoon et al., 2011; de Meij et al., 2010). Total aerosol loading tends to decrease over West Africa, Western Europe and North America, while it is increasing over South Africa and East Asia. Consistent with our expectations, fine-mode dominant aerosol loading, primarily created by human activities, is decreasing over those countries having introduced environmental regulations, while it is increasing over regions in emerging economies without such strict regulations. Temporal variation of the loading of coarse-mode dominant aerosol depends strongly on meteorological conditions varying with climate change. In particular, those AERONET stations close to the regions where rapid desertification plays a role are characterized by a considerable increase of coarse-mode dominant aerosol. After applying classification, these trends are more apparent. In particular, the weighted trends of both CdAOT and FdAOT at Beijing over East Asia show considerable increases. Due to the high density of population in many strongly polluted areas (e.g. 1300 people per $1 \mathrm{~km}^{2}$ in Beijing) and the correlation between aerosol load and mortality (Foster and Kumar, 2011), there is an urgent need for measures to reduce the aerosol load in large urban agglomerations (aka megacities) worldwide similar to those already introduced in Western Europe. 

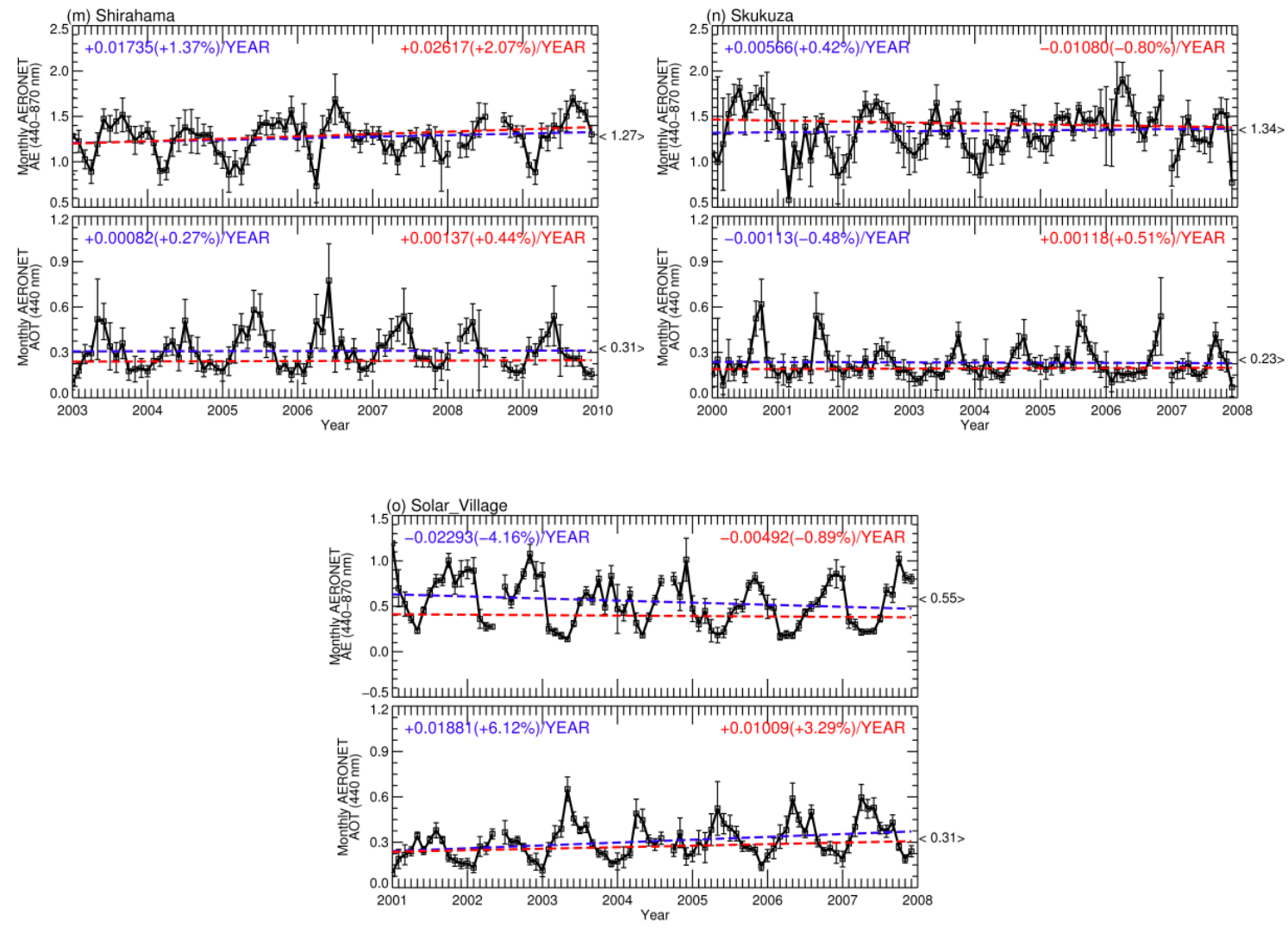

Fig. 7. Continued.

Acknowledgements. This work was supported in part by the CityZen project (megaCITY - Zoom for the Environment: EU Framework Programme 7 of European Commission), the DFG Project Terra, and the University of Bremen. The authors would like to thank NASA AERONET team for the provision of aerosol optical properties data. We are thankful to M. I. Mishchenko for providing the Mie code used in this study. The authors sincerely appreciate your insightful comments and suggestions of the editor (G. de Leeuw), two anonymous referees, and other advisors (D. G. Kaskaoutis and O. Dubovik) for revising the paper.

Edited by: G. de Leeuw

\section{References}

Ackerman, A. S., Toon, O. B., Stevens, D. E., Heymsfield, A. J., Ramanathan, V., and Welton, E. J.: Reduction of tropical cloudiness by soot, Science, 288, 1042-1047, doi:10.1126/science.288.5468.1042, 2000.

Albrecht, B.: Aerosols, cloud microphysics and fractional cloudiness, Science, 245, 1227-1230, doi:10.1126/science.245.4923.1227, 1989.

Andronache, C.: Estimates of sulfate aerosol wet scavenging coefficient for locations in the Eastern United States, Atmos. Environ., 38, 795-804, doi:10.1016/j.atmosenv.2003.10.035, 2004.

Angström, A.: On the atmospheric transmission of sun radiation and on dust in the air, Geograf. Ann. Deut., 11, 156-166, 1929.
Basart, S., Pérez, C., Cuevas, E., Baldasano, J. M., and Gobbi, G. P.: Aerosol characterization in Northern Africa, Northeastern Atlantic, Mediterranean Basin and Middle East from direct-sun AERONET observations, Atmos. Chem. Phys., 9, 8265-8282, doi:10.5194/acp-9-8265-2009, 2009.

Benkovitz, C. M., Scholtz, M. T., Pacyna, J., Tarrason, L., Dignon, J., Voldner, E. C., Spiro, P. A., Logan, J. A., and Graedel, T. E.: Global gridded inventories of antropogenic emissions of sulphur and nitrogen, J. Geophys. Res., 101, 29239-29253, doi:10.1029/96JD00126, 1996.

Bergamo, A., Tafuro, A. M., Kinne, S., De Tomasi, F., and Perrone, M. R.: Monthly-averaged anthropogenic aerosol direct radiative forcing over the Mediterranean based on AERONET aerosol properties, Atmos. Chem. Phys., 8, 6995-7014, doi:10.5194/acp8-6995-2008, 2008.

Chen, L.-W. A., Doddridge, B. G., Dickerson, R. R., Chow, J. C., Mueller, P. K., Quinn, J., and Butler, W. A.: Seasonal variations in elemental carbon aerosol, carbon monoxide and sulfur dioxide: Implications for sources, Geophys. Res. Lett., 28, 17111714, doi:10.1029/2000GL012354, 2001.

Chiapello, J. and Moulin, C.: TOMS and Meteosat satellite records of the variability of Saharan dust transport over the Atlantic during the last two decades (1979-1997), Geophys. Res. Lett., 29, 1176, doi:10.1029/2001GL013767, 2002.

Chiapello, I., Moulin, C., and Prospero, J. M.: Understanding the long-term variability of African dust transport across the Atlantic as recorded in both Barbados surface concen- 

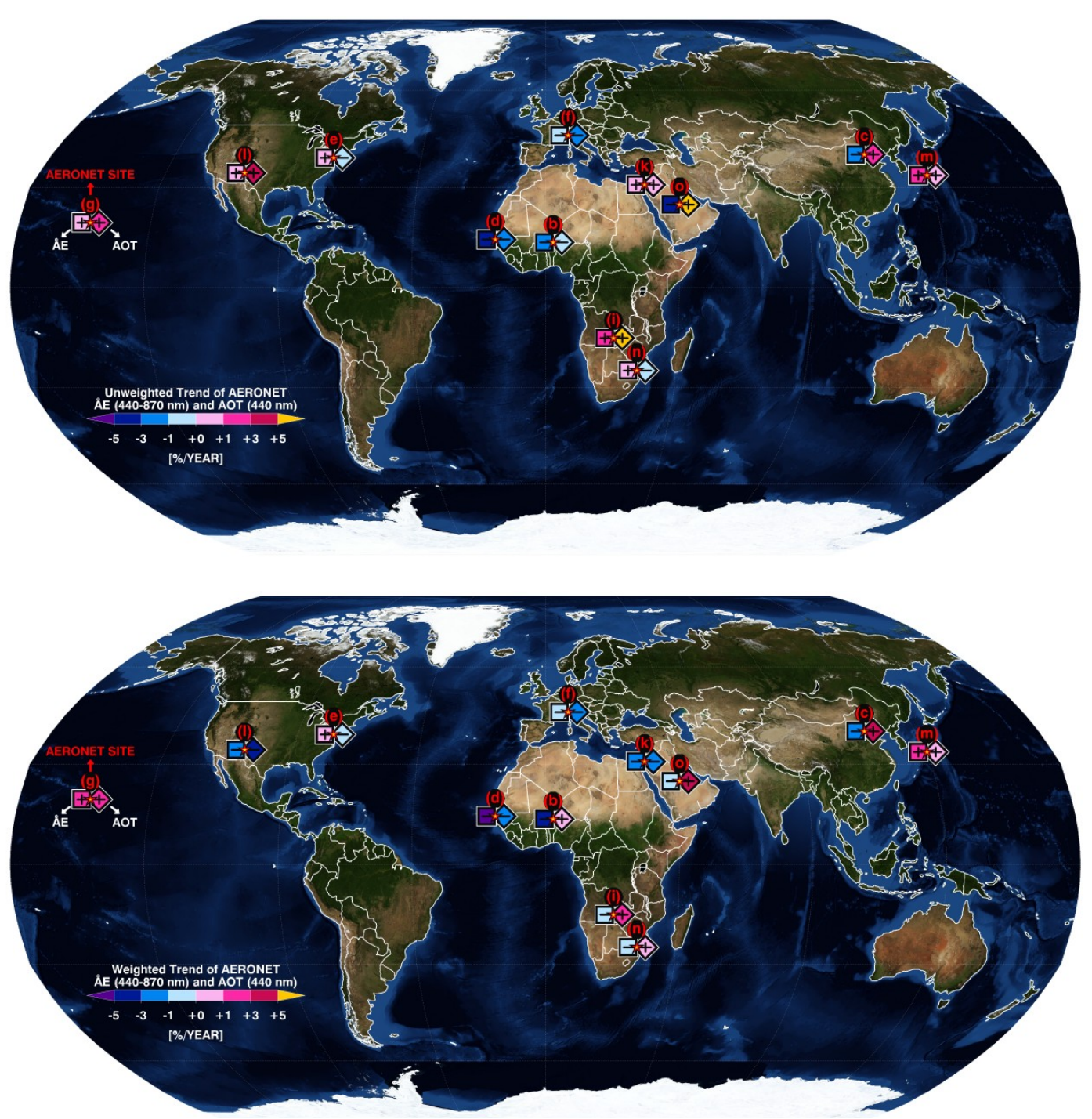

Fig. 8. Unweighted and weighted trends of $\AA E(440-870 \mathrm{~nm})$ (left square) and AOT (440 nm) (right diamond) in percent at the major stations except (a) Avignon over Western Europe, (h) MD_Science_Center over North America, and (j) Ouagadougou over West Africa.

trations and large-scale total ozone mapping spectrometer (TOMS) optical thickness, J. Geophys. Res., 110, D18S10, doi:10.1029/2004JD005132, 2005.

de Meij, A., Pozzer, A., and Lelieveld, J.: Global and regional trends in aerosol optical depth based on remote sensing products and pollutant emission estimates between 2000 and 2009, Atmos. Chem. Phys. Discuss., 10, 30731-30776, doi:10.5194/acpd-1030731-2010, 2010.

Derimian, Y., Karnieli, A., Kaufman, Y. J., Andreae, M. O., Andreae, T. W., Dubovik, O., Maenhaut, W., Koren, I., and Holben, B. N.: Dust and pollution aerosols over the Negev desert, Israel: Properties, transport, and radiative effect, J. Geophys. Res., 111, D05205, doi:10.1029/2005JD006549, 2006.

Dubovik, O. and King, M. D.: A flexible inversion algorithm for retrieval of aerosol optical properties from Sun and sky radiance measurements, J. Geophys. Res., 105, 20673-20696, doi:10.1029/2000JD900282, 2000.
Dubovik, O., Smirnov, A., Holben, B. N., King, M. D., Kaufman, Y. J., Eck, T. F., and Slutsker, I.: Accuracy assessment of aerosol optical properties retrieval from AERONET sun and sky radiance measurements, J. Geophys. Res., 105, 9791-9806, doi:10.1029/2000JD900040, 2000.

Dubovik, O., Holben, B. N., Eck, T. F., Smirnov, A., Kaufman, Y. J., King, M. D., Tanré, D., and Slutsker, I.: Variability of absorption and optical properties of key aerosol types observed in worldwide locations, J. Atmos. Sci., 59, 3, 590-608, doi:10.1175/15200469(2002)059<0590:VOAAOP > 2.0.CO;2, 2002a.

Dubovik, O., Holben, B. N., Lapyonok, T., Sinyuk, A., Mishchenko, M. I., Yang, P., and Slutsker, I.: Non-spherical aerosol retrieval method employing light scattering by spheroids, Geophys. Res. Lett., 29, 1415-1418, doi:10.1029/2001GL014506, 2002b.

Dubovik, O., Sinyuk, A., Lapyonok, T., Holben, B. N., Mishchenko, M., Yang, P., Eck, T. F., Volten, H., Munoz, O., Veihelmann, B., van der Zander, W. J., Leon, J.-F., Sorokin, M., and Slutsker, I.: 

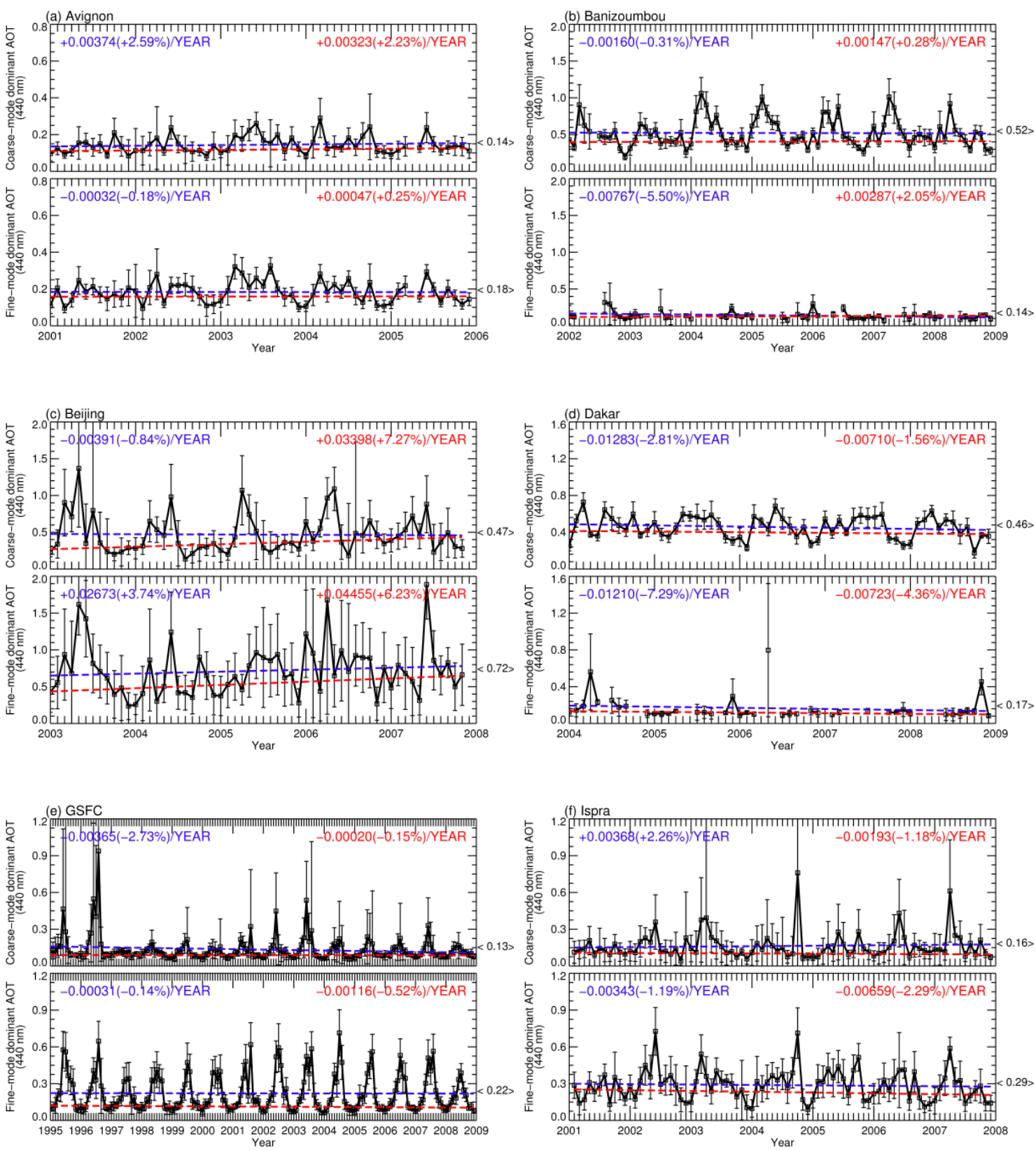

Fig. 9. Unweighted (blue one on the left upper part) and weighted (red one on the right upper part) trends of Coarse- and Fine-mode dominant AOT $(440 \mathrm{~nm})($ CdAOT and FdAOT) at the several AERONET stations. The total means of CdAOT and FdAOT (black one enclosed with parentheses) are shown on right vertical axis. The error bar means the 10 times of the standard error, which are used for the weighted trend analysis. Trend analysis of FdAOT at (b) Banizoumbou, (d) Dakar, (j) Ouagadougou, and (o) Solar_Village might be insignificant because of incomplete yearly datasets.

Application of spheroid models to account for aerosol particle nonsphericity in remote sensing of desert dust, J. Geophys. Res., 111, D11208, doi:10.1029/2005JD006619, 2006.

Eck, T. F., Holben, B. N., Reid, J. S., Dubovik, O., Smirnov, A., O'Neill, N. T., Slutsker, I., and Kinne, S.: Wavelength dependence of the optical depth of biomass burning, urban, and desert dust aerosol, J. Geophys. Res., 104, 31333-31349, doi:10.1029/1999JD900923, 1999.
Eck, T. F., Holben, B. N., Ward, D. E., Dubovik, O., Reid, J. S., Smirnov, A., Mukelabai, M. M., Hsu, N. C., O’Neill, N. T., and Slutsker, I.: Characterization of the optical properties of biomass burning aerosols in Zambia during the 1997 ZIBBEE Field Campaign, J. Geophys. Res., 106, 3425-3448, doi:10.1029/2000JD900555, 2001.

Eck, T. F. Holben, B. N., Ward, D. E., Mukelabai, M. M., Dubovik, O., Smirnov, A., Schafer, J. S., Hsu, N. C., Piketh, 

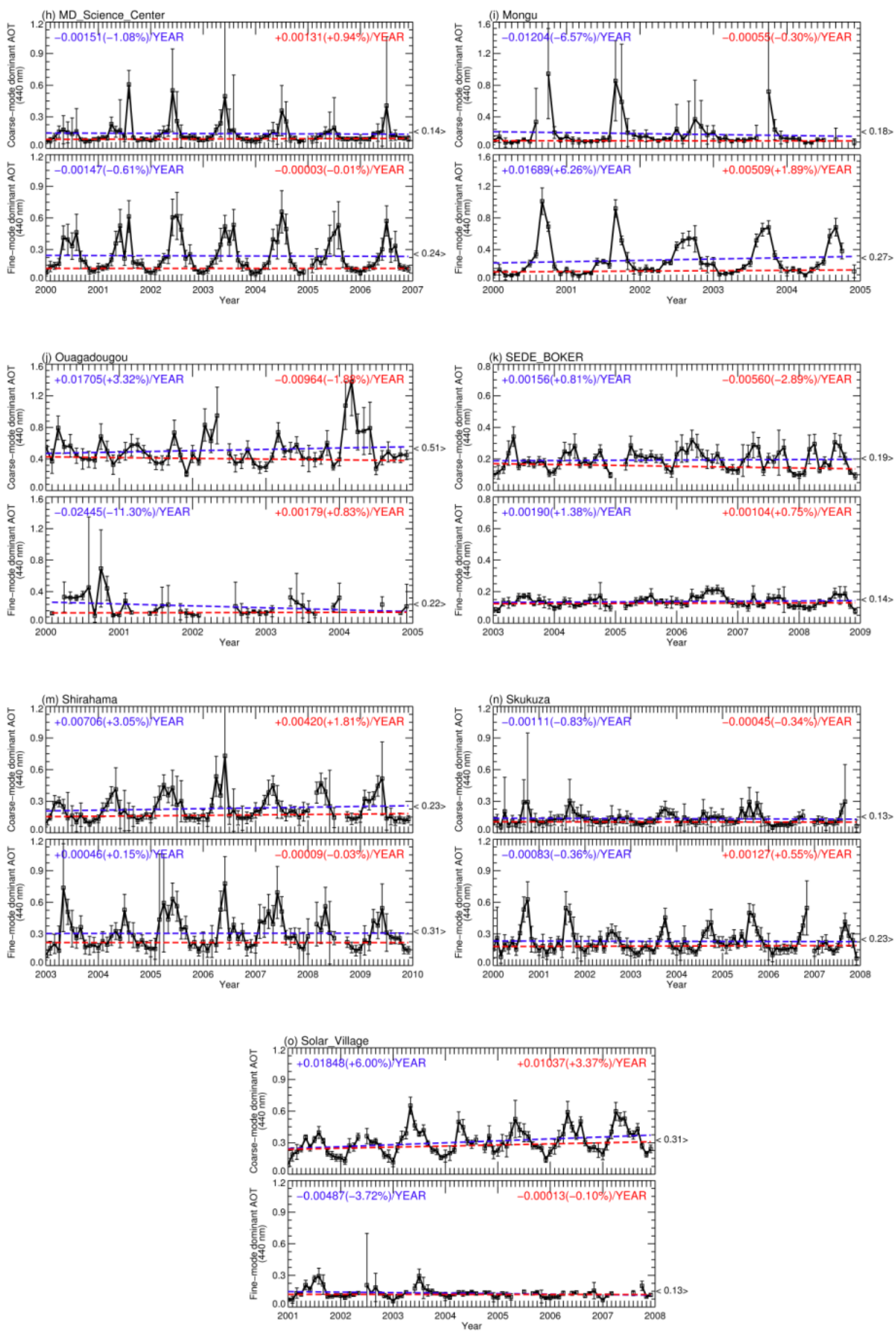

Fig. 9. Continued. 


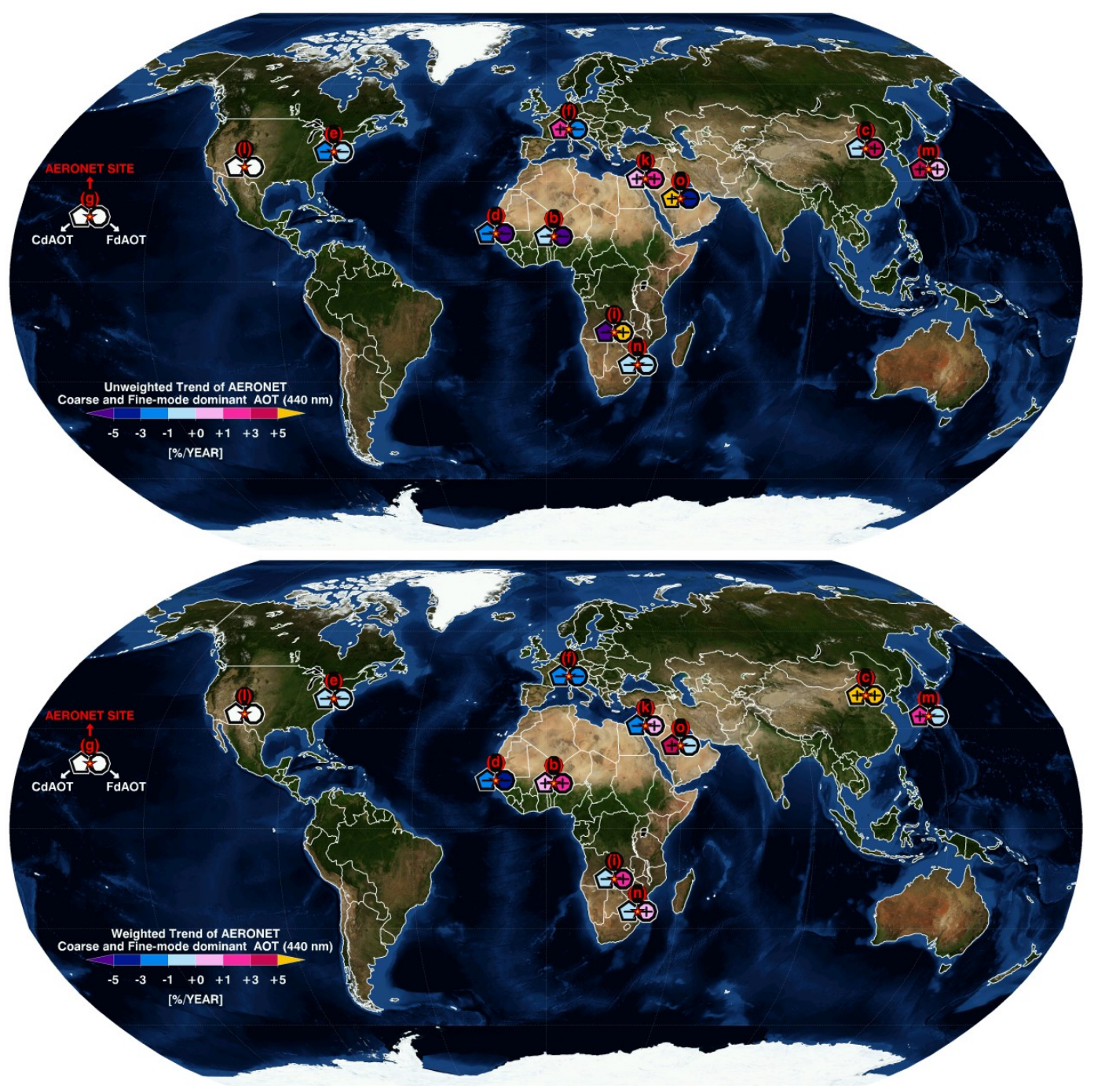

Fig. 10. Unweighted and weighted trends of Coarse- (left pentagon) and Fine-mode (right circle) dominant AOT (440 nm) in percent at the major stations except (a) Avignon over Western Europe, (h) MD_Science_Center over North America, and (j) Ouagadougou over West Africa. Non-applicable cases are shown as a white blank. Trend analysis of FdAOT at (b) Banizoumbou, (d) Dakar, (j) Ouagadougou, and (o) Solar_Village might be insignificant because of incomplete yearly datasets.

S. J., Queface, A., Le Roux, J., Swap, R. J., and Slutsker, I.: Variability of biomass burning aerosol optical characteristics in southern Africa during the SAFARI 2000 dry season campaign and a comparison of single scattering albedo estimates from radiometric measurements, J. Geophys. Res., 108, 8477, doi:10.1029/2002JD002321, 2003.

Eck, T. F., Holben, B. N., Dubovik, O., Smirnov, A., Goloub, P., Chen, H. B., Chatenet, B., Gomes, L., Zhang, X.-Y., Tsay, S.C., Ji, Q., Giles, D., and Slutsker, I.: Columnar aerosol optical properties at AERONET sites in central eastern Asia and aerosol transport to the tropical mid-Pacific, J. Geophys. Res., 110, D06202, doi:10.1029/2004JD005274, 2005.

Eck, T. F., Holben, B. N., Sinyuk, A., Pinker, R. T., Goloub, P., Chen, H., Chatenet, B., Li, Z., Singh, R. P., Tripathi, S. N., Reid, J. S., Giles, D. M., Dubovik, O., O’Neill, N. T., Smirnov, A., Wang, P., and Xia, X.: Climatological aspects of the optical prop- erties of fine/coarse mode aerosol mixtures, J. Geophys. Res., 115, D19205, doi:10.1029/2010JD014002, 2010.

Evan, A. T., Mahowald, N. M., and Remer, L. A.: Global Aerosols, B. Am. Meteorol. Soc., 88, s1-s135, 2007.

Foster, A. and Kumar, N.: Health effects of air quality regulations in Delhi, India, Atmos. Environ., 45, 1675-1683, doi:10.1016/j.atmosenv.2011.01.005, 2011.

Garstang, M. and Fitzjarrald, D. R.: Observations of Surface to Atmosphere Interactions in the Tropics, Oxford University Press, New York, USA, 1999.

Gerasopoulos, E., Andreae, M. O., Zerefos, C. S., Andreae, T. W., Balis, D., Formenti, P., Merlet, P., Amiridis, V., and Papastefanou, C.: Climatological aspects of aerosol optical properties in Northern Greece, Atmos. Chem. Phys., 3, 2025-2041, doi:10.5194/acp-3-2025-2003, 2003. 
Glen, W. G., Zelenka, M. P., and Graham, R. C.: Relating meteorological variables and trends in motor vehicle emissions to monthly urban carbon monoxide concentrations, Atmos. Environ., 30, 4225-4232, doi:10.1016/1352-2310(96)00130-6, 1996.

Gobbi, G. P., Kaufman, Y. J., Koren, I., and Eck, T. F.: Classification of aerosol properties derived from AERONET direct sun data, Atmos. Chem. Phys., 7, 453-458, doi:10.5194/acp-7-453-2007, 2007.

González, R. C., Veefkind, J. P., and de Leeuw, G.: Aerosol optical depth over Europe in August 1997 derived from ATSR-2 data, Geophys. Res. Lett., 27, 955-958, doi:10.1029/1999GL010962, 2000.

Hao, W. M. and Liu, M.: Spatial and temporal distribution of tropical biomass burning, Global Biogeochem. Cy., 8, 495-503, doi:10.1029/94GB02086, 1994.

Haywood, J. and Boucher, O.: Estimates of the direct and indirect radiative forcing due to tropospheric aerosols: A review, Rev. Geophys., 38, 513-543, doi:10.1029/1999RG000078, 2000.

Higurashi, A. and Nakajima, T.: Development of a two channel aerosol retrieval algorithm on global scale using NOAA AVHRR, J. Atmos. Sci., 56, 924-941, doi:10.1175/15200469(1999)056<0924:DOATCA > 2.0.CO;2, 1999.

Holben, B. N., Eck, T. F., Slutsker, I., Tanré, D., Buis, J. P., Setzer, A., Vermote, E., Reagan, J. A., Kaufman, Y. J., Nakajima, T., Lavenu, F., Jankowiak, I., and Smirnov, A.: AERONET - A federated instrument network and data archive for aerosol characteristics, Remote Sens. Environ., 66, 1-16, doi:10.1016/S00344257(98)00031-5, 1998.

Holben, B. N., Tanré, D., Smirnov, A., Eck, T. F., Slutsker, I., Abuhassan, N., Newcomb, W. W., Schafer, J. S., Chatenet, B., Lavenu, F., Kaufman, Y. J., Vande Castle, J., Setzer, A., Markham, B., Clark, D., Frouin, R., Halthore, R., Karneli, A., O’Neill, N. T., Pietras, C., Pinker, R. T., Voss, K., and Zibordi, G.: An emerging ground-based aerosol climatology: Aerosol optical depth from AERONET, J. Geophys. Res., 106, 1206712097, doi:10.1029/2001JD900014, 2001.

Huang, J., Zhang, C., and Prospero, J. M.: African aerosol and large-scale precipitation variability over West Africa, Environ. Res. Lett., 4, 015006, doi:10.1088/1748-9326/4/1/015006, 2009.

Ignatov, A. and Stowe, L.: Sensitivity and information content of aerosol retrievals from AVHRR: Radiometric factors, Appl. Optics, 41, 991-1011, doi:10.1364/AO.41.000991, 2002.

IPCC: Changes in Atmospheric Constituents and in Radiative Forcing: Issues Related to Aerosols, Cambridge Univ. Press, Cambridge, UK, 153-179, 2007.

Jeong, M.-J. and Li, Z.: Quality, compatibility, and synergy analyses of global aerosol products of global aerosol products derived from the advanced very high resolution radiometer and Total Ozone Mapping Spectrometer, J. Geophys. Res., 110, D10S08, doi:10.1029/2004JD004647, 2005.

Jeong, M.-J., Li, Z., Chu, D. A., and Tsay, S.-T.: Quality and compatibility analyses of global aerosol products derived from the advanced very high resolution radiometers and the moderate imaging spectroradiometer, J. Geophys. Res., 110, D10S09, doi:10.1029/2004JD004648, 2005.

Johnson, B. T., Osborne, S. R., Haywood, J. M., and Harrison, M. A. J.: Aircraft measurements of biomass burning aerosol over West Africa during DABEX, J. Geophys. Res., 113, D00C06, doi:10.1029/2007JD009451, 2008a.
Johnson, B. T., Heese, B., McFarlane, S. A., Chazette, P., Jones, A., and Bellouin, N.: Vertical distribution and radiative effects of mineral dust and biomass burning aerosol over West Africa during DABEX, J. Geophys. Res., 113, D00C12, doi:10.1029/2008JD009848, 2008b.

Kahn, R., Li, W.-H., Martonchik, J., Bruegge, C., Diner, D., Gaitley, B., Abdou, W., Dubovik, O., Holben, B., Smirnov, S., Jin, Z., and Clark, D.: MISR low-light-level calibration, and implications for aerosol retrieval over dark water, J. Atmos. Sci., 62, 1032-1062, doi:10.1175/JAS3390.1, 2005.

Kahn, R., Garay, M., Nelson, D., Yau, K., Bull, M., and Martonchik, J.: Satellite-derived aerosol optical depth over dark water from MISR and MODIS: Comparisons with AERONET and implications for climatological studies, J. Geophys. Res., 112, D18205, doi:10.1029/2006JD008175, 2007.

Kambezidisa, H. D. and Kaskaoutisa, D. G.: Aerosol climatology over four AERONET sites: An overview, Atmos. Environ., 42, 1892-1906, doi:10.1016/j.atmosenv.2007.11.013, 2008.

Karnieli, A., Derimian, Y., Indoitu, R., Panov, N., Levy, R. C., Remer, L. A., Maenhaut, W., and Holben, B. N.: Temporal trend in anthropogenic sulfur aerosol transport from central and eastern Europe to Israel, J. Geophys. Res., 114, D00D19, doi:10.1029/2009JD011870, 2009.

Kaskaoutis, D. G. and Kambezidis, H. D.: Comparison of the Ångström parameters retrieval in different spectral ranges with the use of different techniques, Meteorol. Atmos. Phys., 99, 233246, doi:10.1007/s00703-007-0279-y, 2008.

Kaskaoutis, D. G., Kambezidis, H. D., Hatzianastassiou, N., Kosmopoulos, P. G., and Badarinath, K. V. S.: Aerosol climatology: dependence of the Angstrom exponent on wavelength over four AERONET sites, Atmos. Chem. Phys. Discuss., 7, 7347-7397, doi:10.5194/acpd-7-7347-2007, 2007.

Kaskaoutis, D. G., Kumar Kharol, S., Sinha, P. R., Singh, R. P., Kambezidis, H. D., Rani Sharma, A., and Badarinath, K. V. S.: Extremely large anthropogenic-aerosol contribution to total aerosol load over the Bay of Bengal during winter season, Atmos. Chem. Phys., 11, 7097-7117, doi:10.5194/acp-11-70972011, 2011, 2011a.

Kaskaoutis, D. G., Kharol, S. K., Sinha, P. R., Singh, R. P., Badarinath, K. V. S., Mehdi, W., and Sharma, M.: Contrasting aerosol trends over South Asia during the last decade based on MODIS observations, Atmos. Meas. Tech. Discuss., 4, 52755323, doi:10.5194/amtd-4-5275-2011, 2011b.

Kaufman, Y. J.: Aerosol optical thickness and atmospheric path radiance, J. Geophys. Res., 98, 2677-2692, 1993.

Kim, S.-W., Yoon, S.-C., Kim, J., and Kim, S.-Y.: Seasonal and monthly variations of columnar aerosol optical properties over East Asia determined from multi-year MODIS, LIDAR, and AERONET sun/sky radiometer measurements, Atmos. Environ., 41, 1634-1651, doi:10.1016/j.atmosenv.2006.10.044, 2007.

Kokhanovsky, A. and de Leeuw, G.: Satellite aerosol remote sensing over land, Springer, 2009.

Kotchenruther, R., Hobbs, P. V., and Hegg, D. A.: Humidification factors for atmospheric aerosols off the mid-Atlantic coast of the United States, J. Geophys. Res., 104, 2239-2251, doi:10.1029/98JD01751, 1999.

Kubilay, N., Cokacar, T., and Oguz, T.: Optical properties of mineral dust outbreaks over the northeastern Mediterranean, J. Geophys. Res., 108, 4666, doi:10.1029/2003JD003798, 2003. 
Li, Z., Zhao, X., Kahn, R., Mishchenko, M., Remer, L., Lee, K.-H., Wang, M., Laszlo, I., Nakajima, T., and Maring, H.: Uncertainties in satellite remote sensing of aerosols and impact on monitoring its long-term trend: a review and perspective, Ann. Geophys., 27, 2755-2770, doi:10.5194/angeo-27-2755-2009, 2009.

Liu, Y., Sarnat, J. A., Coull, B. A., Koutrakis, P., and Jacob, D. J.: Validation of Multiangle Imaging Spectroradiometer (MISR) aerosol optical thickness measurements using Aerosol Robotic Network (AERONET) observations over the contiguous United States, J. Geophys. Res., 109, D06205, doi:10.1029/2003JD003981, 2004.

Marmer, E., Langmann, B., Fagerli, H., and Vestreng, V.: Direct shortwave radiative forcing of sulphate aerosol over Europe from 1900 to 2000, J. Geophys. Res., 112, D23S17, doi:10.1029/2006JD008037, 2007.

Massie, T. S., Torres, O., and Smith, S. J.: Total ozone mapping spectrometer (TOMS) observations of increases in Asian aerosol in winter from 1979 to 2000 , J. Geophys. Res., 109, D18211, doi:10.1029/2004JD004620, 2004.

Mazzola, M., Lanconelli, C., Lupi, A., Busetto, M., Vitale, V., and Tomasi, C.: Columnar aerosol optical properties in the Po Valley, Italy, from MFRSR data, J. Geophys. Res., 115, D17206, doi:10.1029/2009JD013310, 2010.

Mishchenko, M. and Geogdzhayev, I. V.: Satellite remote sensing reveals regional tropospheric aerosol trends, Opt. Express, 15, 7423-7438, 2007.

Mishchenko, M. I., Geogdzhayev, I. V., Cairns, B., Rossow, W. B., and Lacis, A. A.: Aerosol retrievals over the ocean by use of channels 1 and 2 AVHRR data: sensitivity analysis and preliminary results, Appl. Optics, 38, 7325-7341, 1999a.

Mishchenko, M. I., Dlugach, J. M., Yanovitskij, E. G., and Zakharova, N. T.: Bidirectional reflectance of flat, optically thick particulate laters: an efficient radiative transfer solution and applications to snow and soil surfaces, J. Quant. Spectrosc. Ra., 63, 409-432, doi:10.1016/S0022-4073(99)00028-X, 1999b.

Mishchenko, M. I., Travis, L. D., and Lacis, A. A.: Scattering, Absorption, and Emission of Light by Small Particles, Cambridge University Press, 2002.

Mishchenko, M., Geogdzhayev, I. V., Rossow, W. B., Cairns, B., Carlson, B. E., Lacis, A. A., Liu, L., and Travis, L. D.: Longterm satellite record reveals likely recent aerosol trend, Science, 315, 1543, doi:10.1126/science.1136709, 2007.

Moulin, C. and Chiapello, I.: Evidence of the control of summer atmospheric transport of African dust over the Atlantic by Sahel sources from TOMS satellites (1979-2000), Geophys. Res. Lett., 31, L02107, doi:10.1029/2003GL018931, 2004.

Mukai, S., Sano, I., and Holben, B.N.: Aerosol properties over Japan by sun/sky photometry, Water Air Soil Pollut., 5, 133-143, doi:10.1007/s11267-005-0731-2, 2005.

Mukai, S., Sano, I., Satoh, M., and Holben, B. N.: Aerosol properties and air pollutants over an urban area, Atmos. Res., 82, 643651, doi:10.1016/j.atmosres.2006.02.020, 2006.

Norris, J. R. and Wild, M.: Trends in aerosol radiative effects over Europe inferred from observed cloud cover, solar "dimming", and solar "brightening", J. Geophys. Res., 112, D08214, doi:10.1029/2006JD007794, 2007.

O’Neill, N. T., Dubovik, O., and Eck, T. F.: A modified Angstrom coefficient for the characterization of sub-micron aerosols, Appl. Optics, 40, 2368-2374, 2001a.
O’Neill, N. T., Eck, T. F., Holben, B. N., Smirnov, A., and Dubovick, O.: Bimodal size distribution influences on the variation of Angstrom derivatives in spectral and optical depth space, J. Geophys. Res., 106, 9787-9806, doi:10.1029/2000JD900245, $2001 b$.

O’Neill, N. T., Eck, T. F., Smirnov, A., Holben, B. N., and Thulasiraman, S.: Spectral discrimination of coarse and fine mode optical depth, J. Geophys. Res., 108, 4559, doi:10.1029/2002JD002975, 2003.

O’Neill, N. T., Thulasiraman, S., Eck, T. F., and Reid, J. S.: Robust optical features of fine mode size distributions: Application to the Quebec smoke event of 2002, J. Geophys. Res., 110, D11207, doi:10.1029/2004JD005157, 2005.

Ohmura, A.: Observed long-term variations of solar irradiance at the Earth's surface, Space Sci. Rev., 125, 111-128, doi:10.1007/s11214-006-9050-9, 2006.

Pereira, S. N., Wagner, F., and Silva, A. M.: Seven years of measurements of aerosol scattering properties, near the surface, in the southwestern Iberia Peninsula, Atmos. Chem. Phys., 11, 1729, doi:10.5194/acp-11-17-2011, 2011.

Perry, K. D., Cahill, T. A., Schnell, R. C., and Harris, J. M.: Long-range transport of anthropogenic aerosols to the National Oceanic and Atmospheric Administration baseline station at Mauna Loa Observatory, Hawaii, J. Geophys. Res., 104, 1852118533, doi:10.1029/1998JD100083, 1999.

Pincus, R. and Baker, M. B.: Effect of precipitation on the albedo susceptibility of clouds in the marine boundary layer, Nature, 372, 250-252, doi:10.1038/372250a0, 1994.

Prospero, J. M. and Lamb, J. P.: African droughts and dust transport to the Caribbean: climate change and implications, Science, 302, 1024-1027, doi:10.1126/science.1089915, 2003.

Reeves, C. E., Formenti, P., Afif, C., Ancellet, G., Attié, J.-L., Bechara, J., Borbon, A., Cairo, F., Coe, H., Crumeyrolle, S., Fierli, F., Flamant, C., Gomes, L., Hamburger, T., Jambert, C., Law, K. S., Mari, C., Jones, R. L., Matsuki, A., Mead, M. I., Methven, J., Mills, G. P., Minikin, A., Murphy, J. G., Nielsen, J. K., Oram, D. E., Parker, D. J., Richter, A., Schlager, H., Schwarzenboeck, A., and Thouret, V.: Chemical and aerosol characterisation of the troposphere over West Africa during the monsoon period as part of AMMA, Atmos. Chem. Phys., 10, 7575-7601, doi:10.5194/acp-10-7575-2010, 2010.

Reid, J. S., Eck, T. F., Christopher, S. A., Hobbs, P. V., and Holben, B. N.: Use of the Angstrom exponent to estimate the variability of optical and physical properties of aging smoke particles in Brazil, J. Geophys. Res., 104, 27473-27489, doi:10.1029/1999JD900833, 1999.

Remer, L. A., Gasso, S., Hegg, D. A., Kaufman, Y. J., and Holben, B. N.: Urban/industrial aerosol: Ground-based sun/sky radiometer and airborne in situ measurements, J. Geophys. Res., 102, 16849-16859, doi:10.1029/96JD01932, 1997.

Sabbah, I. and Hasan, F. M.: Remote sensing of aerosols over the Solar Village, Saudi Arabia, Atmos. Res., 90, 170-179, doi:10.1016/j.atmosres.2008.02.004, 2008.

Sabbah, I., Saeed, T., Al Jassar, H. K., and Rao, K. S.: Remote sensing of desert dust in Kuwait, J. Sci. Eng., 33, 101-117, 2006.

Sano, I., Mukai, S., Okada, Y., Holben, B. N., Ohta, S., and Takamura, T.: Optical properties of aerosols during APEX and ACE-Asia experiments, J. Geophys. Res., 108, 8649, doi:10.1029/2002JD003263, 2003. 
Schmeissner, T., Krejci, R., Ström, J., Birmili, W., Wiedensohler, A., Hochschild, G., Gross, J., Hoffmann, P., and Calderon, S.: Analysis of number size distributions of tropical free tropospheric aerosol particles observed at Pico Espejo (4765 m a.s.1.), Venezuela, Atmos. Chem. Phys., 11, 3319-3332, doi:10.5194/acp-11-3319-2011, 2011.

Schuster, G. L., Dubovick, O., and Holben, B. N.: Angstrom exponent and bimodal aerosol size distributions, J. Geophys. Res., 111, D07207, doi:10.1029/2005/JD006328, 2006.

Shinozuka, Y., Redemann, J., Livingston, J. M., Russell, P. B., Clarke, A. D., Howell, S. G., Freitag, S., O’Neill, N. T., Reid, E. A., Johnson, R., Ramachandran, S., McNaughton, C. S., Kapustin, V. N., Brekhovskikh, V., Holben, B. N., and McArthur, L. J. B.: Airborne observation of aerosol optical depth during ARCTAS: vertical profiles, inter-comparison and fine-mode fraction, Atmos. Chem. Phys., 11, 3673-3688, doi:10.5194/acp-11-36732011, 2011.

Sinyuk, A., Dubovik, O., Holben, B. N., Eck, T. F., Breon, F.M., Martonchik, J., Kahn, R., Diner, D. J., Vermote, E. F., Roger, J.-C., Lapyonok, T., and Slutsker, I.: Simultaneous retrieval of aerosol and surface properties from a combination of AERONET and satellite data, Remote Sens. Environ., 107, 90108, doi:10.1016/j.rse.2006.07.022, 2007.

Smirnov, A., Holben, B. N., Eck, T. F., Dubovik, O., and Slutsker, I.: Cloud screening and quality control algorithms for the AERONET data base, Remote Sens. Environ., 73, 3, 337-349, doi:10.1016/S0034-4257(00)00109-7, 2000.

Smirnov, A., Holben, B. N., Dubovik, O., Neil, N., and Eck, T. F.: Atmospheric aerosol optical properties in the Persian Gulf, Atmos. Sci., 59, 620-634, doi:10.1175/15200469(2002)059<0620:AAOPIT>2.0.CO;2, 2002.

Smith, S. J., Pitcher, H., and Wigley, T. M. L.: Global and regional anthropogenic sulfur dioxide emissions, Global Planet. Change, 29, 99-119, doi:10.1016/S0921-8181(00)00057-6, 2001.

Smith, S. J., Andres, R., Conception, E., and Lurz, J.: Historical sulfur dioxide emissions 1850-2000: Methods and results, PNNL Res. Rep. 14537, Pac. Northwest Natl. Lab., Richland, Wash, 2003.

Stanhill, G.: A perspective on global warming, dimming, and brightening, EOS Trans. Am. Geophys. Union, 88, 58, doi:10.1029/2007EO050007, 2007.

Streets, D. G., Tsai, N. Y., Akimoto, H., and Oka, K.: Sulfur dioxide emissions in Asia in the period 1985-1997, Atmos. Environ., 34, 4413-4424, doi:10.1016/S1352-2310(00)00187-4, 2000.

Streets, D. G., Bond, T. C., Carmichael, G. R., Fernandes, S. D., Fu, Q., He, D., Klimont, Z., Nelson, S. M., Tsai, N. Y., Wang, M. Q., Woo, J.-H., and Yarber, K. F.: An inventory of gaseous and primary aerosol emissions in Asia in the year 2000, J. Geophys. Res., 108, 8809, doi:10.1029/2002JD003093, 2003.

Streets, D. G., Wu, Y., and Chin, M.: Two-decadal aerosol trends as a likely explanation of the global dimming/brightening transition, Geophys. Res. Lett., 33, L15806, doi:10.1029/2006GL026471, 2006.

Streets, D. G., Yan, F., Chin, M., Diehl, T., Mahowald, N., Schultz, M., Wild, M., Wu, Y., and Yu, C.: Anthropogenic and natural contributions to regional trends in aerosol optical depth, 1980-2006, J. Geophys. Res., 114, D00D18, doi:10.1029/2008JD011624, 2009.
Swap, R., Garstang, M., Macko, S. A., Tyson, P. D., Maenhaut, W., Artaxo, P., Kållberg, P., and Talbot, R.: The ong-range transport of southern African aerosols to the tropical South Atlantic, J. Geophys. Res., 101, 23777-23791, 1996.

Tafuro, A. M., Barnaba, F., De Tomasi, F., Perrone, M. R., and Gobbi, G. P.: Saharan dust particle properties over the central Mediterranean, Atmos. Res., 81, 67-93, doi:10.1016/j.atmosres.2005.11.008, 2006.

Tanré, D., Bréon, F. M., Deuzé, J. L., Herman, M., Goloub, P., Nadal, F., and Marchand, A.: Global observation of anthropogenic aerosols from satellite, Geophys. Res. Lett., 28, 45554558, doi:10.1029/2001GL013036, 2001.

Thomas, G. E., Poulsen, C. A., Siddans, R., Sayer, A. M., Carboni, E., Marsh, S. H., Dean, S. M., Grainger, R. G., and Lawrence, B. N.: Validation of the GRAPE single view aerosol retrieval for ATSR-2 and insights into the long term global AOD trend over the ocean, Atmos. Chem. Phys., 10, 4849-4866, doi:10.5194/acp-10-4849-2010, 2010.

Twomey, S. A.: The influence of pollution on the shortwave albedo of clouds, J. Atmos. Sci., 34, 1149-1152, doi:10.1175/15200469(1977)034<1149:TIOPOT>2.0.CO;2, 1977.

Tyson, P. D.: Climatic Change and Variability in Southern Africa, Oxford Univ. Press, 220-221,, 1986.

Venzac, H., Sellegri, K., Villani, P., Picard, D., and Laj, P.: Seasonal variation of aerosol size distributions in the free troposphere and residual layer at the puy de Dôme station, France, Atmos. Chem. Phys., 9, 1465-1478, doi:10.5194/acp-9-1465-2009, 2009.

von Hoyningen-Huene, W., Yoon, J., Vountas, M., Istomina, L. G., Rohen, G., Dinter, T., Kokhanovsky, A. A., and Burrows, J. P.: Retrieval of spectral aerosol optical thickness over land using ocean color sensors MERIS and SeaWiFS, Atmos. Meas. Tech., 4, 151-171, doi:10.5194/amt-4-151-2011, 2011.

Washington, R. and Todd, M. C.: Atmospheric controls on mineral dust emission from the Bodélé depression, chad: the role of the low level jet, Geophys. Res. Lett., 32, L17701, doi:10.1029/2005GL023597, 2005.

Wild, M., Gilgen, H., Roesch, A., Ohmura, A., Long, C. N., Dutton, E. G., Forgan, B., Kallis, A., Russak, V., and Tsvetkov, A.: From dimming to brightening: Decadal changes in solar radiation at Earth's surface, Science, 308, doi:10.1126/science.1103215, 847-850, 2005.

Wild, M., Ohmura, A., and Makowski, K.: Impact of global dimming and brightening on global warming, Geophys. Res. Lett., 34, L04702, doi:10.1029/2006GL028031, 2007.

Yoon, J., von Hoyningen-Huene, W., Vountas, M., and Burrows, J. P.: Analysis of linear long-term trend of aerosol optical thickness derived from SeaWiFS using BAER over Europe and South China, Atmos. Chem. Phys., 11, 12149-12167, doi:10.5194/acp11-12149-2011, 2011.

Yu, H., Chin, M., Remer, L. A., Kleidman, R. G., Bellouin, N., Bian, H., and Diehl, T.: Variability of marine aerosol finemode fraction and estimates of anthropogenic aerosol component over cloud-free oceans from the Moderate Resolution Imaging Spectroradiometer (MODIS), J. Geophys. Res., 114, D10206, doi:10.1029/2008JD010648, 2009.

Zhang, J. and Reid, J. S.: A decadal regional and global trend analysis of the aerosol optical depth using a data-assimilation grade over-water MODIS and Level 2 MISR aerosol products, Atmos. Chem. Phys., 10, 10949-10963, doi:10.5194/acp-10- 
10949-2010, 2010

Zhang, X. Y., Gong, S. L., Zhao, T. L., Arimoto, R., Wang, T. Q., and Zhou, Z. J.: Sources of Asian dust and role of climate change versus desertification in Asian dust emission, Geophys. Res. Lett., 30, 2272, doi:10.1029/2003GL018206, 2003.
Zhao, T. X.-P., Laszlo, I., Guo, W., Heidinger, A., Cao, C., Jelenak, A., Tarpley, D., and Sullivan, J.: Study of long-term trend in aerosol optical thickness observed from operational AVHRR satellite instrument, J. Geophys. Res., 113, D07201, doi:10.1029/2007JD009061, 2008. 